
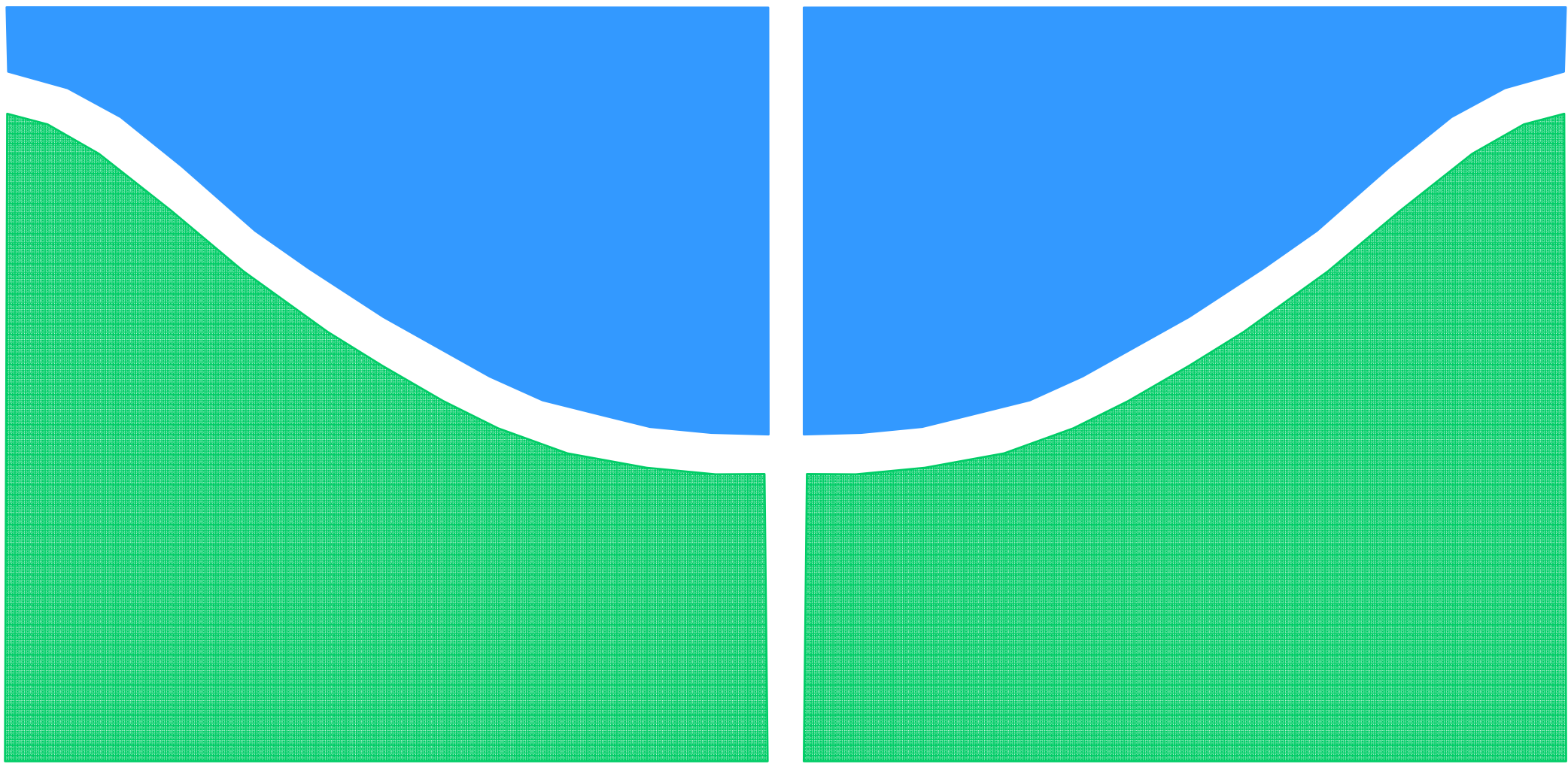

\title{
IMPLEMENTAÇÃO DE UM RECEPTOR DRM BASEADO EM SOFTWARE
}

Cristiano Chaves Campos Rezende Marcelo Tutida Calixto Nunes

\section{UNIVERSIDADE DE BRASILIA}

FACULDADE DE TECNOLOGIA 
UNIVERSIDADE DE BRASILIA

Faculdade de Tecnologia

\title{
TRABALHO DE GRADUAÇÃO
}

\section{IMPLEMENTAÇÃO DE UM RECPTOR DRM BASEADO EM SOFTWARE}

\author{
Cristiano Chaves Campos Rezende \\ Marcelo Tutida Calixto Nunes
}
Relatório submetido ao Departamento de Engenharia
Elétrica como requisito parcial para obtenção
do grau de Engenheiro Eletricista

\section{Banca Examinadora}

Prof. Lúcio Martins Silva, UnB/ Dep (Orientador)

Prof. Rafael Granja Neves, UnB/ Dep

Prof. Flávio Ferreira Lima, UnB/ Dep 
Dedico aos meus pais, Vanessa e Alberone, aos meus irmãos, Leonardo e Juliana, à minha avó Isolina e a minha namorada Juliana.

\author{
Cristiano Chaves
}

Dedico aos meus pais, Felipe e Hélia.

Marcelo Tutida 


\section{Agradecimentos}

A Deus, por me dar saúde, sabedoria e perseverança em minha vida.

A meus pais, por me ensinarem valores como honestidade, trabalho e amor.

A minha avó, pelo carinho e pela força.

A meus irmãos, pela amizade, união e por acreditarem em mim.

A minha namorada, pela dedicação, paciência e companheirismo.

A toda minha família, pelo incentivo.

Cristiano Chaves 


\section{RESUMO}

Nessa dissertação foram apresentados alguns circuitos abaixadores de freqüência que são a porta de entrada para demodulação de um sinal DRM através do software, em um computador pessoal. As experiências obtidas bem como os circuitos mais eficientes e fáceis de se implementar foram discutidos em detalhes. O processo de montagem desde a modificação do rádio comercial, implementação do circuito abaixador de freqüência, recepção no computador pessoal e demodulação através do software, foram apresentados juntamente com as explicações teóricas necessárias ao entendimento do processo como um todo.Uma discussão dos assuntos relacionados a transmissão digital DRM também foi apresentada.

ABSTRACT

In this dissertation were presented some frequency down-converter circuits that are the gateway for a signal demodulation through the DRM software on a personal computer. The experiences obtained and the circuit more efficient and easy to implement were discussed in detail. The process of assembly since the modification of the commercial radio, implementation of the frequency downconverter circuits, reception at the personal computer and demodulation through software, were presented together with the necessary explanations to the theoretical understanding of the process. A discussion of the issues related to DRM digital transmission was also presented. 
1 INTRODUÇÃO.......................................................................................................1

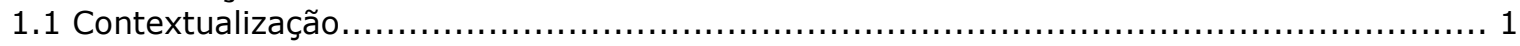

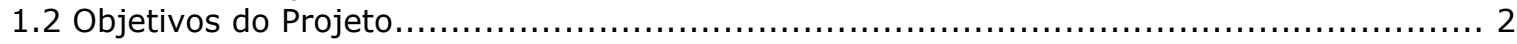

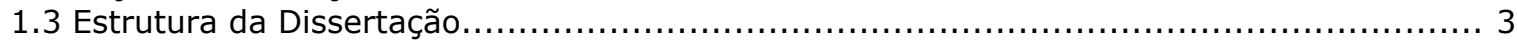

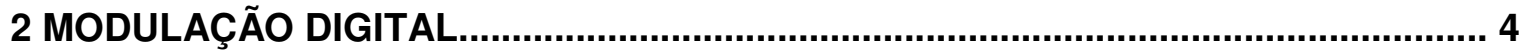

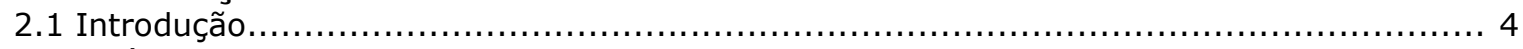

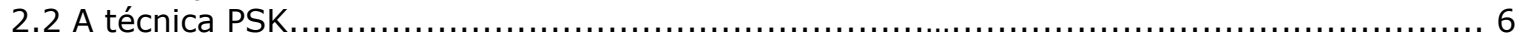

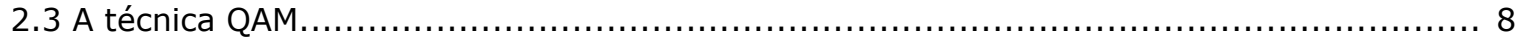

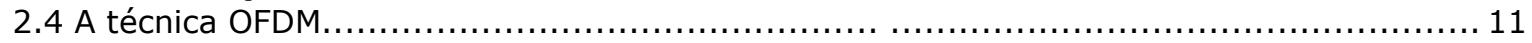

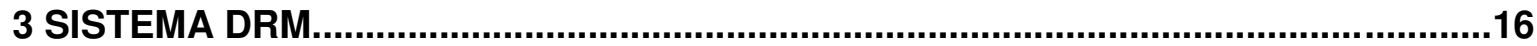

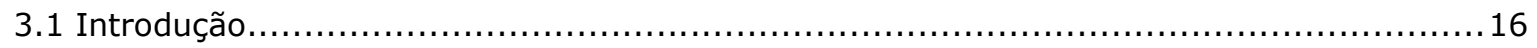

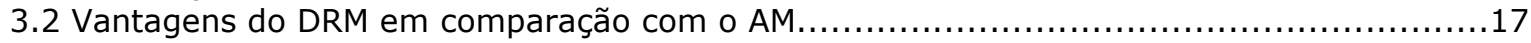

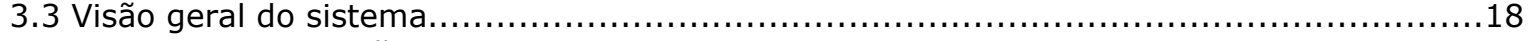

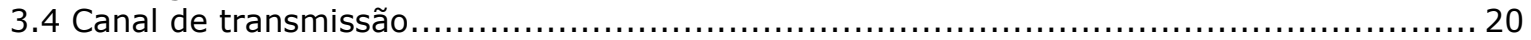

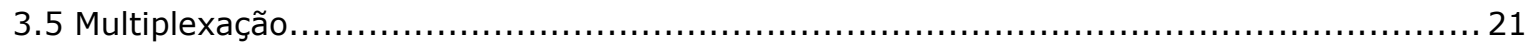

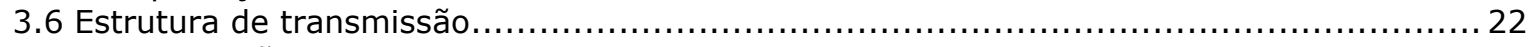

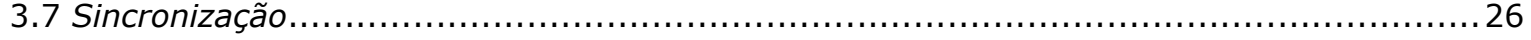

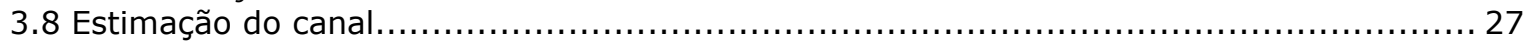

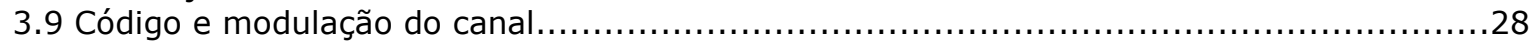

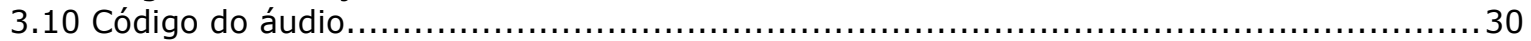

4 O RECEPTOR DREAM BASEADO EM SOFTWARE................................................34

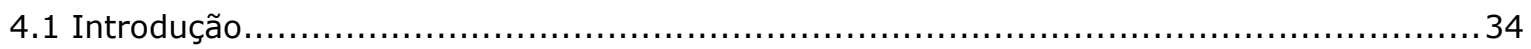

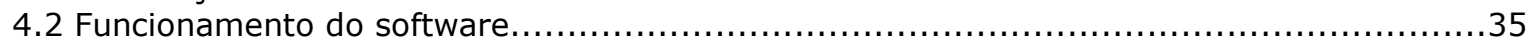

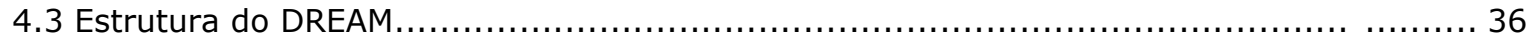

5 ADAPTAÇÕES PARA RECEPÇÃO...................................................................40

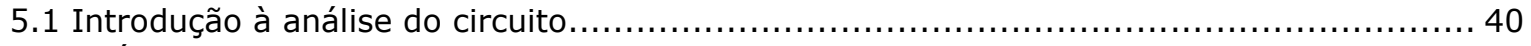

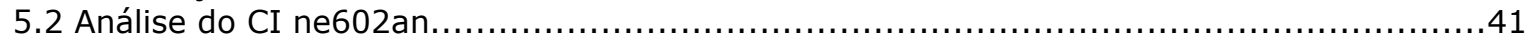

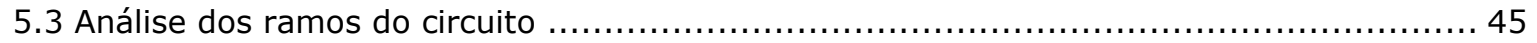

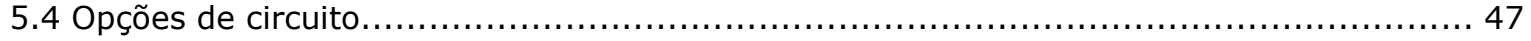

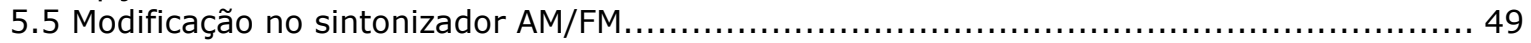

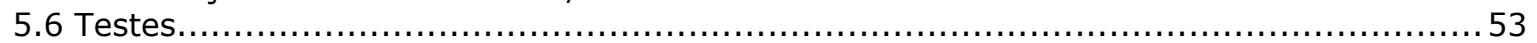

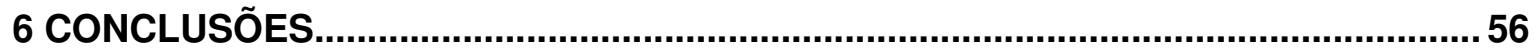

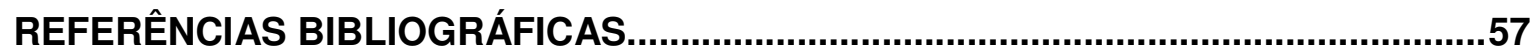




\section{LISTA DE FIGURAS}

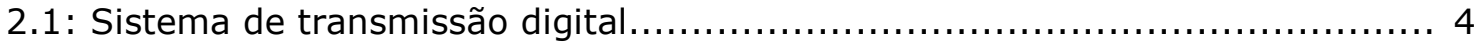

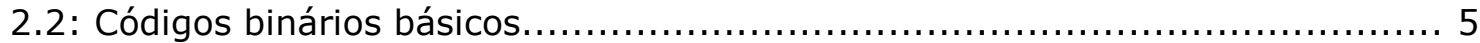

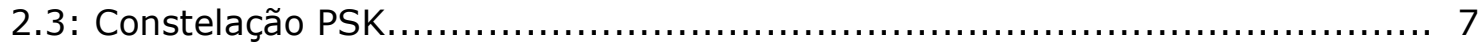

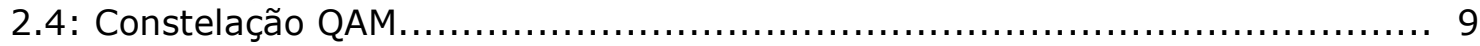

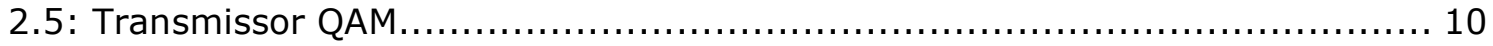

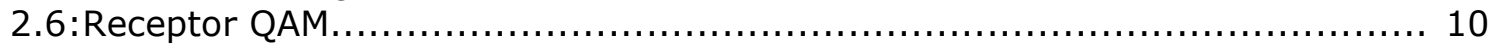

2.7: Espectros OFDM: domínio do tempo e domínio da freqüência.................. 12

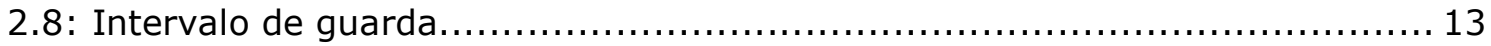

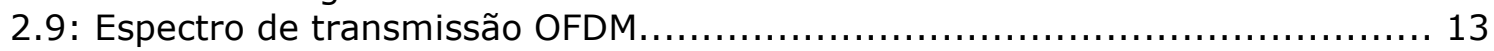

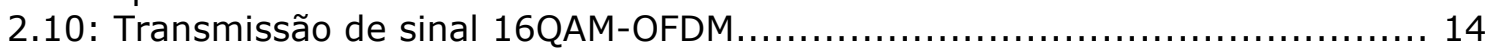

2.11: Sistema de transmissão/Recepção OFDM.................................. 15

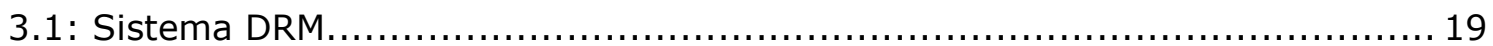

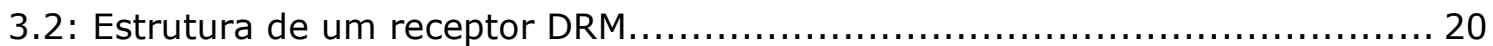

3.3: Propagação de ondas nas bandas AM......................................... 21

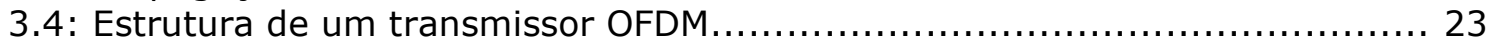

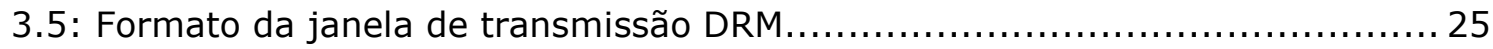

3.6: Padrão piloto para o modo B do DRM............................................. 26

3.7: Comparação do MSE entre o filtro Wiener e o estimador baseado na DFT..... 28

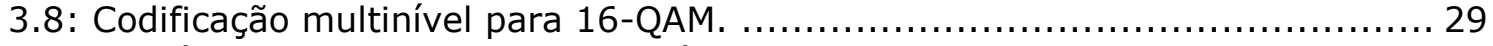

3.9: Princípio de um decodificador de áudio....................................... 31

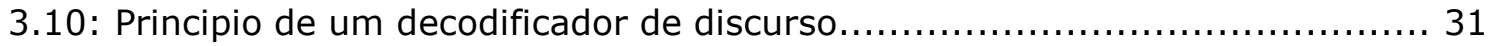

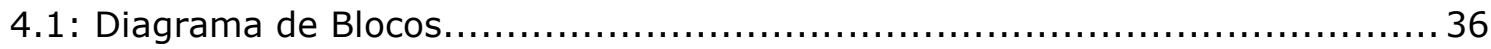

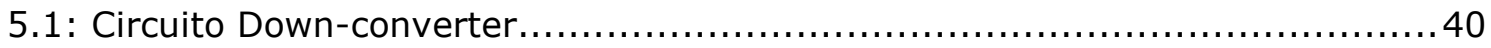

5.2: CI NE602AN: esquemático e estrutura interna................................. 42

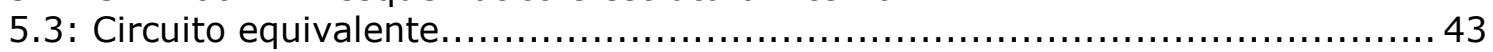

5.4: Configurações do circuito oscilador............................................... 44

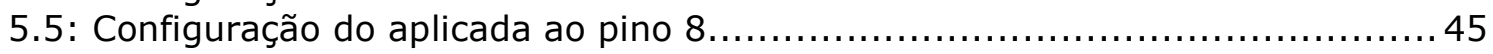

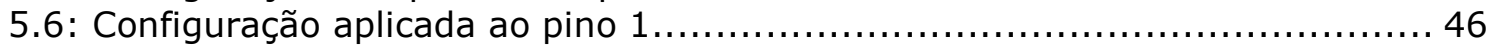

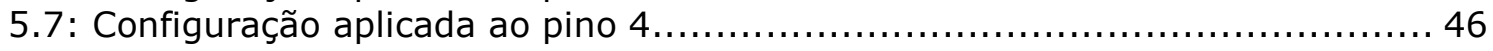

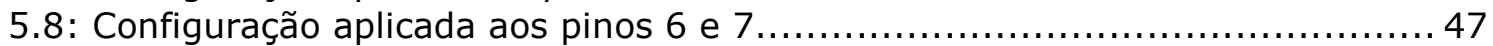

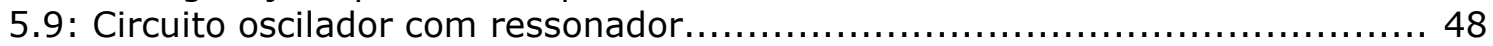

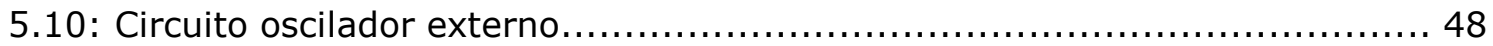

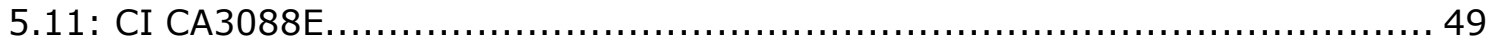

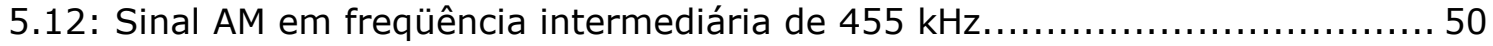

5.13: Espectro 1 do sinal AM em freqüência intermediária de $455 \mathrm{kHz} \ldots \ldots \ldots \ldots \ldots . \ldots 50$

5.14: Espectro 2 do sinal $A M$ em freqüência intermediária de $455 \mathrm{kHz} \ldots \ldots \ldots \ldots \ldots . \ldots 1$

5.15: Sinal AM na saída do down-converter...................................... 51

5.16: Espectro 1 do sinal AM na saída do down-converter............................ 52

5.17: Espectro 2 do sinal AM na saída do down-converter............................ 52

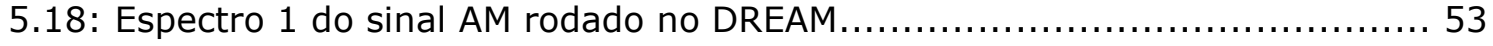

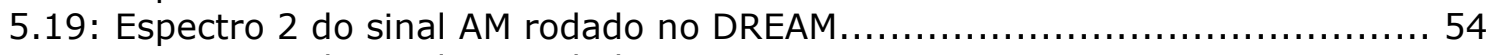

5.20: Espectro 3 do sinal AM rodado no DREAM.................................. 54 


\section{LISTA DE TABELAS}

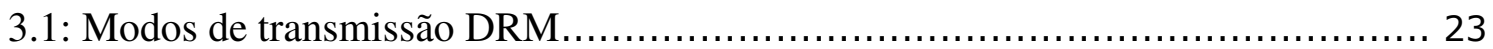

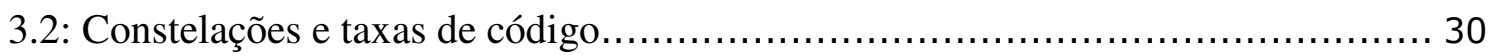

3.3: Características dos códigos de áudio DRM...................................... 33 


\section{LISTA DE SÍMBOLOS}

SIGLAS

\begin{tabular}{|c|c|}
\hline $\mathrm{AAC}$ & Advanced Audio Coding \\
\hline AM & Amplitude Modulation \\
\hline AMDS & Data System in Monophonic AM Sound Broadcasting \\
\hline ASK & Modulação por Chaveamento de Amplitude \\
\hline AWGN & Additive White Gaussian Noise \\
\hline BER & Bit Error Ratio \\
\hline BPSK & Modulação por Chaveamento de Fase Binário \\
\hline CELP & Code Excited Linear Prediction \\
\hline CIR & Channel Impulse Response \\
\hline DAB & Digital Audio Broadcasting \\
\hline DFT & Discrete Fourier Transform \\
\hline DPSK & Diferencial Phase Shift Keying \\
\hline DRM & Digital Radio Mondiale \\
\hline DSB & Double Sideband \\
\hline DVB-T & Digital Video Broadcasting Terrestrial \\
\hline EEP & Equal Error Protection \\
\hline ETSI & European Telecommunications Standards Institute \\
\hline FAC & Fast Access Channel \\
\hline FM & Frequency Modulation \\
\hline FSK & Frequency Shift Keying \\
\hline GNU & General Public License \\
\hline GPS & Global Positioning System \\
\hline $\mathrm{HF}$ & High Frequency \\
\hline HVXC & Harmonic Vector Excitation Coding \\
\hline Iboc & In-Band On-Channel \\
\hline IDFT & Inverse Discrete Fourier Transform \\
\hline ISDB-TSB & Integrated Services Digital Broadcasting \\
\hline ISI & Inter Symbol Interference \\
\hline ITU & International Telecommunication Union \\
\hline $\mathrm{LF}$ & Low Frequency \\
\hline LPC & Linear Predictive Coding \\
\hline MDCT & Modified Discrete Cosine Transform \\
\hline MF & Medium Frequency \\
\hline MLC & Multilevel Coding \\
\hline MPEG & Moving Picture Experts Group \\
\hline MSC & Main Service Channel \\
\hline MSE & Mean Square Error \\
\hline NRZ & Não Retorna ao Zero \\
\hline OFDM & Orthogonal Frequency-Division Multiplexing \\
\hline $\mathrm{PC}$ & Personal Computer \\
\hline PRBS & Pseudorandom Binary Sequence \\
\hline PSK & Phase Shift Keying \\
\hline
\end{tabular}


QAM Quadrature amplitude modulation

QPSK Quadrature Phase Shift Keying

RZ Retorna ao Zero

SBR Spectral Band Replication

SDC

Service Description Channel 


\section{INTRODUÇÃO}

\subsection{CONTEXTUALIZAÇÃO}

Nas ultimas décadas, com o avanço e a popularização das tecnologias de comunicação, a demanda por informação tem crescido muito. O acesso aos vários serviços como os de telefonia móvel, internet, canais de televisão a cabo e via satélite, bem como o barateamento dos aparelhos de recepção, telefones celulares e computadores pessoais, permitiram que essa demanda por novos serviços e a melhoria de qualidade fossem, cada vez mais, o objeto de investimento das grandes empresas do setor tecnológico.

A necessidade de qualidade e quantidade de informações cresce todos os dias e já não está restrita apenas aos ambientes de trabalho e de estudo, criando também oportunidades em outros campos da economia como, por exemplo, o turismo, a propaganda e o comércio em geral. Seja no trabalho ou simplesmente para entretenimento, há também a necessidade de poder comunicar-se com o restante de mundo, em qualquer lugar e a qualquer hora, de maneira interativa. Atualmente, serviços via satélite permitem que, em qualquer região do planeta, seja possível assistir televisão, receber chamadas telefônicas, ou então obter as coordenadas geográficas do ponto onde se está por meio de um GPS. Passou-se, então, a falar muito em convergência digital, isto é, a oferta integrada de serviços de telefonia celular, internet e televisão utilizando a mesma rede. E esta é uma questão que abrange tanto aspectos tecnológicos quanto jurídicos, e que deve ser amplamente debatida nos próximos anos.

Neste trabalho foi priorizado o estudo e a realização de teste com tecnologia de rádio digital. Com a chegada dessa tecnologia as principais novidades serão: a agregação de componentes de interatividade, a possibilidade da transmissão de mais de um programa simultaneamente, a melhoria significativa na qualidade do som, concedendo às estações AM a qualidade de som equivalente às estações FM atuais, e às FM, som com qualidade de $\mathrm{CD}$, o fim das interferências na transmissão das emissoras AM e a convergência de mídias - o que possibilitará a transmissão de textos e imagens, visualizados por meio de uma tela no aparelho de rádio digital. Há também a possibilidade da ampliação do número de emissoras. Todavia, para se ter acesso a tais melhorias não basta esperar a conversão do 
sistema analógico (atual) para o digital. O ouvinte terá que arcar com a compra de um aparelho de som compatível com a tecnologia digital, caso contrário não conseguirá observar diferença alguma. A adaptação ao sistema digital vai requerer a compra de equipamentos, tais como novos transmissores e adaptadores de transmissores analógicos. Diante do custo elevado, o governo acena com a possibilidade de desenvolver ações visando ao barateamento do processo. Os custos aos radiodifusores e ouvintes não são às únicas barreiras para que o rádio digital se estabeleça no pais, há, ainda, a escolha do padrão a ser adotado. Existem quatro consórcios internacionais distintos que oferecem padrões de transmissão de rádio digital, são eles: o Iboc (In-Band On-Channel), oriundo dos Estados Unidos; o DAB Eureka (Digital Audio Broadcasting) e o DRM, (Digital Radio Mondiale), ambos europeus, e, finalmente, o ISDB-TSB (Integrated Services Digital Broadcasting - Terrestrial), do Japão. Embora exista estas quatro opções, somente dois desses padrões foram aprovados pela União Internacional de Telecomunicações, ITU: o Iboc e o DRM. É justamente entre os dois que o debate em torno da escolha do padrão a ser adotado no Brasil, vem se intensificando. Diante dessa dupla possibilidade, a escolha pelo padrão adequado ao contexto brasileiro deve vir por meio de testes com os dois sistemas, para assim decidir qual é o mais vantajoso.

\subsection{OBJETIVOS DO PROJETO}

O objetivo central deste trabalho é o desenvolvimento de um sistema para testes de recepção de um sinal DRM. A implementação de alguns abaixadores de freqüência para adaptar a freqüência intermediária de um sintonizador comercial à entrada da placa de som

de um PC, foi a motivação central da presente dissertação, a estrutura é mostrada na figura 1.1. Esses circuitos foram comparados e discutidos mostrando suas vantagens e desvantagens em relação ao custo, estabilidade e dificuldade de implementação. Tendo desenvolvido o circuito adaptador foi possível transladar o sinal para uma freqüência suficientemente baixa para que a taxa de amostragem da placa de som do PC digitalizasse o sinal. Assim a demodulação através de um software (DREAM) permite que os testes de áudio possam ser realizados. 


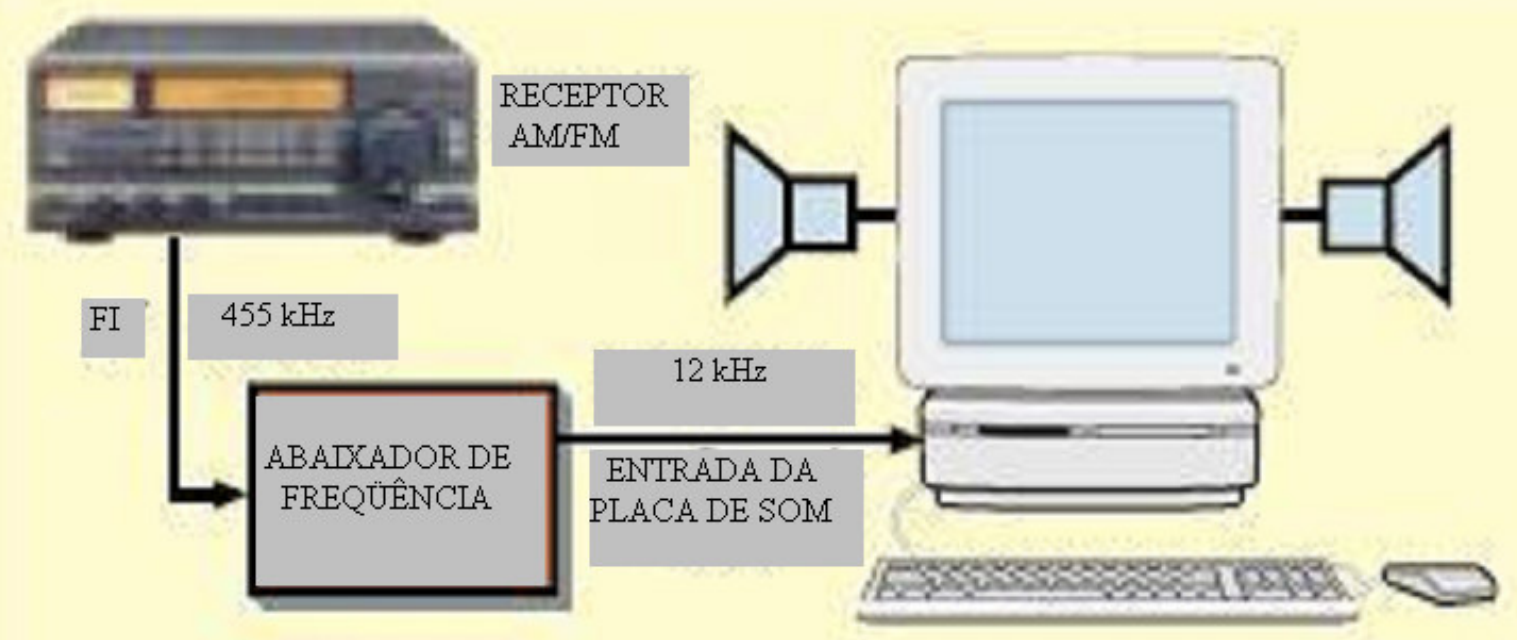

Figura 1.1: Estrutura de Recepção

\subsection{ESTRUTURA DA DISSERTAÇÃO}

No capítulo 2 é feita uma explicação dos principais processos de modulação utilizados pelo sistema de transmissão digital DRM, os quais são de fundamental importância para o entendimento do processo de transmissão, que é objeto do capitulo 3. Além da transmissão uma descrição pormenorizada da técnica DRM é feita no capitulo 3. No capitulo 4 são apresentados conceitos e informações básicas acerca do software DREAM que é o responsável pela demodulação digital do sinal DRM. O capitulo 5 é o desfecho do trabalho onde, depois de conhecida toda a teoria proposta sobre o sistema de transmissão DRM, é apresentado o circuito abaixador de freqüência (downconverter) juntamente com a adaptação do sintonizador comercial e os teste são realizados. 


\section{MODULAÇÃO DIGITAL}

\subsection{INTRODUÇÃO}

No passado, a transmissão digital de vídeo e áudio exigia uma banda de freqüências maior do que a utilizada em transmissões analógicas para transmitir a mesma informação. Os recentes progressos na tecnologia da fonte de codificação de vídeo e áudio, no entanto, permitiram reduzir a taxa de bits e, ao mesmo tempo, manter a qualidade com deterioração mínima. A banda de frequiência necessária para transmissão digital tem consequentemente se tornado quase igual ou frações das requeridas pela transmissão analógica, tornando viável os sistemas de radiodifusão digital.

Até recentemente, os sistemas de transmissão digital para radiodifusão consistiram principalmente na multiplexação de sistemas de transmissão que só transmitiam áudio e informações de texto. Hoje a transmissão digital incluindo serviços de vídeo é possível por satélite e por transmissões digitais terrestres. Vamos descrever os fundamentos dos sistemas de modulação da era digital.

A Figura 2.1 mostra um sistema de transmissão digital. O sistema faz a quantização e amostra informações analógicas como vídeo, áudio ou dados e executa a codificação, objetivando a compressão da banda de dados.

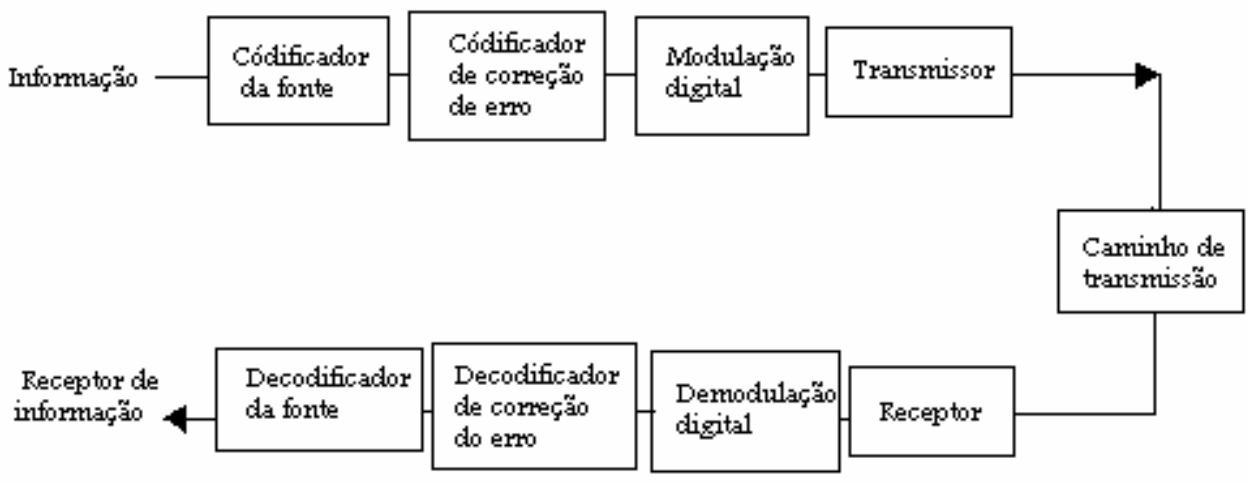

Figura 2.1: Sistema de transmissão digital 
Ele então executa a codificação do canal, que consiste em adicionar código de correção de erro para corrigir os erros gerados durante a transmissão. O sistema converte o sinal digital modulado a ser transmitido no transmissor, em outro na freqüência da banda de transmissão, amplifica o sinal e o transmite por uma das ondas portadoras ou por cabo. No receptor, o sistema executa o processo inverso ao realizado no lado do transmissor para restaurar a informação original na banda de freqüência original.

O código base de um sistema digital consiste em um fluxo de dados representados por 0's e 1's que podem ser transmitidos como um trem de pulsos gerado, por exemplo, pela tensão de um sinal elétrico. Códigos binários básicos para um trem de pulsos são mostradas na Figura 2.2

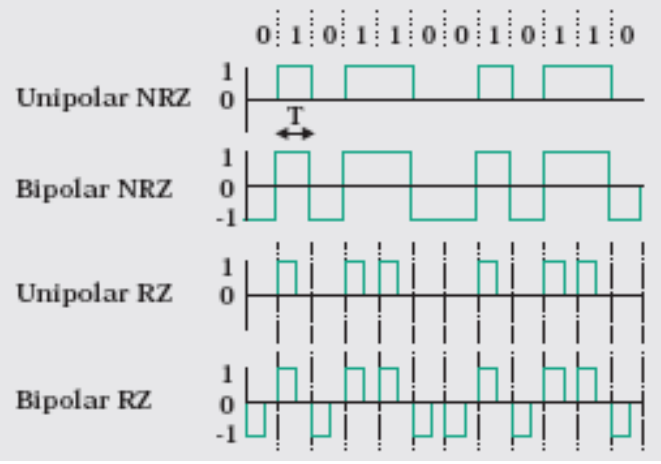

Figura 2.2: Códigos binários básicos

Referindo-se a Figura 2.2, "unipolar" significa que a entrada de dados 0 e 1 correspondem às tensões de $0 \mathrm{~V}$ e $+1 \mathrm{~V}$ respectivamente, enquanto "bipolar" significa que a entrada de dados 0 e 1 correspondem às tensões de $-1 \mathrm{~V}$ e $+1 \mathrm{~V}$ respectivamente. Aqui, RZ (retorna ao Zero) resulta em um pulso de largura estreita, o que significa que a freqüência é maior do que em NRZ (não retorna ao zero), por esta razão NRZ é frequentemente mais utilizado como um sinal de banda base para modulação digital em transmissões de rádio.

Como na modulação analógica, a função da "modulação" nas modulações digitais é converter o sinal original de informações (sinal em banda base) em outro com uma freqüência conveniente para a transmissão, para isso variando a amplitude, a frequiência, ou a fase da portadora. $\mathrm{O}$ que é diferente na modulação analógica é que o sinal em banda base pode ser um sinal analógico ou um sinal digital. Dessa forma a modulação digital pode ser comparada à modulação analógica da seguinte forma: variando a amplitude da portadora como no AM, conforme os 1's e 0's do sinal de banda base temos a modulação por 
chaveamento de amplitude (ASK); variando a freqüência da portadora como em FM, temos a modulação por chaveamento de freqüência (FSK); variando a fase temos a modulação por chaveamento de fase(PSK) e variando tanto amplitude como a fase, temos modulação de amplitude em quadratura (QAM).

\subsection{A TÉCNICA PSK}

A modulação por chaveamento de fase (PSK) é um sistema que transmite dados alterando ou modulando a fase de um sinal de referência, a onda portadora[1]. Qualquer sistema digital de modulação utiliza um número finito de sinais para representar dados digitais, o PSK utiliza um número finito de fases para representar, cada qual, um único conjunto de bits binários. Normalmente, cada fase codifica um número igual de bits e cada padrão de bits que constitui o símbolo é representado por uma fase específica.

O demodulador, que é projetado especificamente para detectar os símbolos utilizados pelo modulador, determina a fase do sinal recebido e recupera o símbolo que ela representa, assim são obtidos os dados originais. Para isso é necessário um receptor que compare a fase do sinal recebido com um sinal de referência. Esse tipo de receptor é denominado receptor coerente. Alternativamente, em vez de utilizar um bit padrão para definir a fase da onda, pode ser usado um conjunto específico, assim o demodulador determina, em seguida, as alterações na fase do sinal recebido, em vez da fase em si. Esse esquema depende de uma diferença entre as fases sucessivas e é denominado modulação por chaveamento diferencial de fase (DPSK). O DPSK pode ser significativamente mais simples de se implementar do que o PSK, pois não há a necessidade do demodulador ter uma cópia do sinal de referência para determinar a exata fase do sinal recebido (trata-se de um regime não coerente), porém ele produz mais erros na demodulação.

Uma forma conveniente de representar esquemas PSK é sobre a forma de constelação. Ela mostra os pontos no plano cartesiano, onde o eixo real e o imaginário são denominados, respectivamente, eixo em fase e eixo em quadratura. Essa representação nos eixos perpendiculares tornam mais simples a implementação. A amplitude de cada ponto ao longo do eixo em fase é usada para modular uma onda cossenoidal e a amplitude ao longo 
do eixo em quadratura para modular uma onda senoidal. No PSK, os pontos da constelação são escolhidos de forma a ficarem igualmente espaçados em torno de um círculo. Isso dá a máxima separação de fase entre pontos adjacentes e, portanto, a melhor imunidade a deterioração. Eles estão posicionados em um círculo, a fim de que tudo possa ser transmitido com a mesma energia, como mostrado na Figura 2.3.

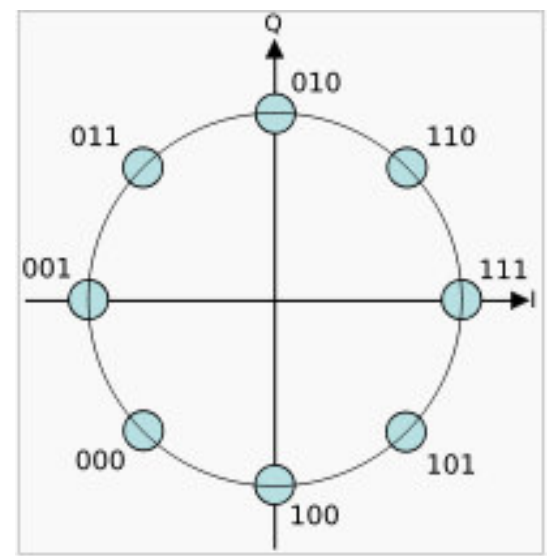

Figura 2.3: Constelação PSK

Desta forma, o módulo dos números complexos representados será o mesmo e, assim, portanto, terá as amplitudes necessárias para as ondas seno e cosseno. Dois exemplos são comuns: BPSK, que usa duas fases, e o QPSK, que utiliza quatro fases, embora qualquer número de fases possa ser utilizado. Uma vez que os dados a serem transmitidos são geralmente binário, o esquema PSK é normalmente projetado com o número de pontos da constelação sendo uma potência de 2. Apesar de qualquer número de fases poder ser utilizado para construir uma constelação PSK, a 8-PSK geralmente é a maior constelação desenvolvida. Com mais de 8 fases, a taxa de erro torna-se demasiadamente elevada. 


\subsection{A TÉCNICA QAM}

A modulação de amplitude em quadratura (QAM) é um esquema de modulação que transmite dados alterando, modulando, a amplitude das duas ondas portadora[2]. Estas duas ondas, normalmente senóides, estão fora de fase entre si em $90^{\circ} \mathrm{e}$, assim, são chamados portadoras em quadratura. Quando dois sinais são modulados no esquema QAM, o sinal transmitido terá a seguinte forma:

$$
\mathrm{s}(\mathrm{t})=I(t) \cos \left(2 \pi f_{0} \mathrm{t}\right)+Q(t) \operatorname{sen}\left(2 \pi f_{0} \mathrm{t}\right)
$$

onde I ( $\mathrm{t}$ e e $\mathrm{Q}(\mathrm{t})$, são os sinais modulados e $\mathrm{f}_{0}$ é a freqüência da portadora.

No receptor, estes dois sinais modulados podem ser demodulados usando um demodulador coerente. Esse receptor multiplica o sinal recebido por uma cossenóide e por uma senóide, separadamente, para produzir as estimativas recebidas de I (t) e de Q (t), respectivamente. Devido à ortogonalidade das portadoras, é possível detectar os sinais modulados independente. No caso ideal, o sinal I (t) é demodulado pela multiplicação do sinal transmitido com um sinal cosseno:

$$
\mathrm{r}_{\mathrm{i}}(\mathrm{t})=s(t) \cos \left(2 \pi f_{0} \mathrm{t}\right)=I(t) \cos \left(2 \pi f_{0} \mathrm{t}\right) \cos \left(2 \pi f_{0} \mathrm{t}\right)+Q(t) \operatorname{sen}\left(2 \pi f_{0} \mathrm{t}\right) \cos \left(2 \pi f_{0} \mathrm{t}\right)
$$

Usando identidades trigonométricas, podemos escrevê-lo como:

$$
\begin{aligned}
\mathrm{r}_{\mathrm{i}}(\mathrm{t}) & =\frac{1}{2} I(t)\left[1+\cos \left(4 \pi f_{0} \mathrm{t}\right)\right]+\frac{1}{2} \mathrm{Q}(\mathrm{t}) \operatorname{sen}\left(4 \pi f_{0} \mathrm{t}\right) \\
& =\frac{1}{2} I(t)+\frac{1}{2}\left[I(t) \cos \left(4 \pi f_{0} \mathrm{t}\right)+\mathrm{Q}(\mathrm{t}) \operatorname{sen}\left(4 \pi f_{0} \mathrm{t}\right)\right]
\end{aligned}
$$

Com um filtro passa baixa remove-se termos de alta freqüência do sinal $r_{i}(t)$ deixando apenas o termo I (t), não afetado por Q ( $t$ ). Da mesma forma, podemos multiplicar s(t) por uma onda seno e, em seguida, com um filtro passa baixas extrair $Q(t)$. 
Deve notar-se que aqui estamos presumindo que a fase do sinal recebido é conhecida no receptor. Se o demodulador de fase não esta sincronizado, isso resultará em interferência entre os sinais modulados. Esta questão da sincronização da portadora no receptor deve ser muito bem acertada em sistemas QAM, de forma que o demodulador coerente precisa estar exatamente em fase com o sinal recebido, ou de outra forma os sinais não poderão ser recebidos independentemente.

Semelhantemente a outros esquemas de modulação digital, a constelação é uma representação útil. Em QAM os pontos da constelação são situados em um grande quadrado com igual espaçamento vertical e horizontal, embora outras configurações sejam possíveis, sendo que as formas mais comuns são 16 - QAM, 64 - QAM, 128 - QAM e 256 - QAM.

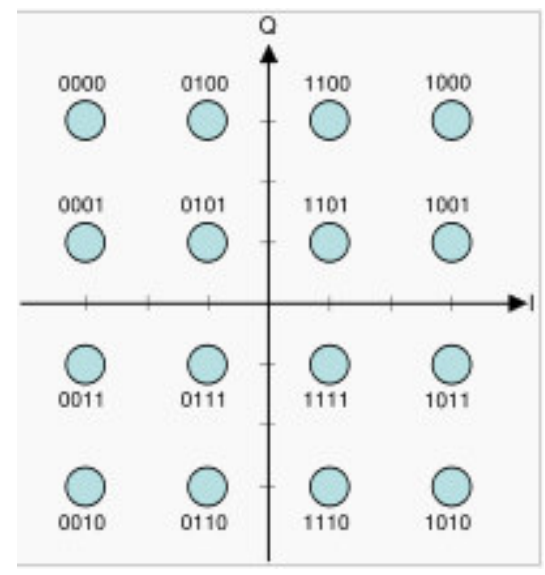

Figura 2.4: Constelação QAM

Ao mover-se de uma constelação de ordem inferior para uma de ordem superior, é possível transmitir mais bits por símbolos, no entanto, a medida que a constelação cresce, os pontos tornam-se mais próximos e, portanto, são mais sensíveis ao ruído e outros formas de degradação. Isso resulta em uma percentagem de erro mais elevada, logo quanto maior a constelação menor confiabilidade de erro. Se a taxa de dados vai além da disponível pelo 8PSK é mais comum a utilização do esquema QAM, uma vez que ele proporciona uma maior distância entre pontos adjacentes no plano I-Q, distribuindo-os mais uniformemente. A complicação é que os pontos já não são todos da mesma amplitude e assim o demodulador tem que detectar corretamente tanto fase quanto a amplitude, em vez de apenas fase. 
A Figura 2.5 mostra a estrutura ideal de um transmissor QAM, com uma portadora de frequiência $\mathrm{f}_{0}$ e $\mathrm{H}_{\mathrm{s}}$ sendo a resposta em freqüência do filtro transmissor.

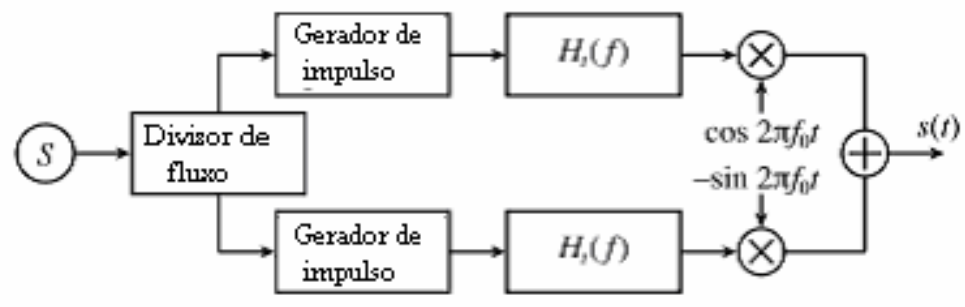

Figura 2.5: Transmissor QAM

Primeiro, o fluxo de bits a ser transmitido é dividido em duas partes iguais: este processo gera dois sinais independente a serem transmitidos. Eles são codificados separadamente. Em seguida, um canal (em fase) é multiplicado por um cosseno, enquanto o outro canal (em quadratura) é multiplicado por um seno. Desta maneira, há uma fase de $90^{\circ}$ entre eles. Eles são simplesmente adicionado e enviados através do canal real.

O receptor simplesmente executa o processo inverso do realizado pelo transmissor. Sua estrutura ideal é mostrada na Figura 2.6 abaixo, onde $\mathrm{H}_{\mathrm{s}}$ é a reposta em frequiência do filtro do receptor.

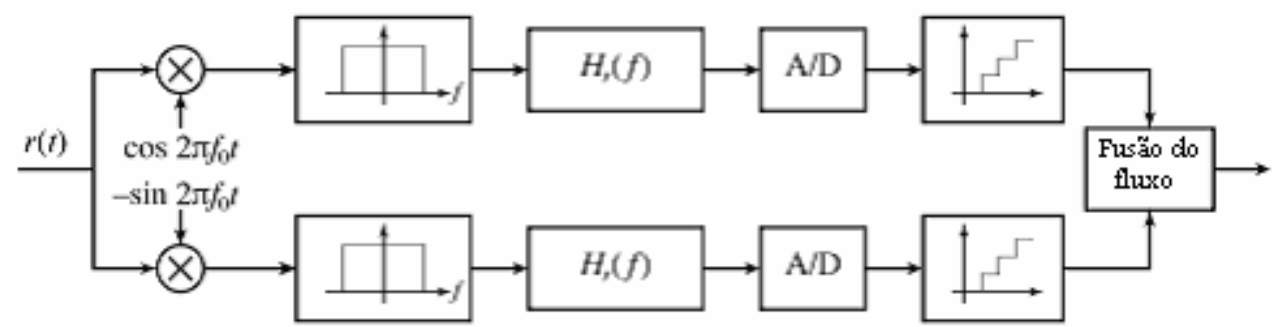

Figura 2.6:Receptor QAM

Multiplicando por um cosseno (ou um seno) e passando por um filtro passa baixa, é possível extrair o componente em fase (ou em quadratura). Na prática, existe um atraso de fase desconhecido entre o transmissor e receptor que deve ser compensado pela sincronização dos osciladores locais do receptor, isto é, as funções seno e cosseno da figura acima. 


\subsection{A TÉCNICA OFDM}

O OFDM é um sistema de modulação digital que utiliza multiportadoras e que tem sido empregado em transmissão digital terrestre. Comparado com a modulação digital de portadora única, a técnica OFDM pode prolongar o período de um símbolo enquanto mantém as mesmas características de taxa de erro e de eficiência de banda[3]. Pode também adicionar um período de sinal redundante denominado intervalo de guarda. Por estas razões as características do sinal OFDM sofrem pouca deterioração durante a transmissão, devido a ação dos multipercursos, que são o principal tipo de perturbação em um sistema de transmissão terrestre.

O sinal OFDM multiplexado contém várias ondas moduladas digitalmente e que são mutuamente ortogonais num certo intervalo do sinal. Referindo-se a Figura 2.7, se, para frequiências em banda base, tomarmos a portadora 1 como sendo a onda base e fizermos que as demais subportadoras sejam múltiplos inteiros dessa portadora, então todo o conjunto dessas portadoras serão mutuamente ortogonais dentro de um período de onda base. Variando a amplitude e fase de cada uma destas portadoras por técnicas de modulação digital e, em seguida, somando-as resulta em um sinal OFDM 


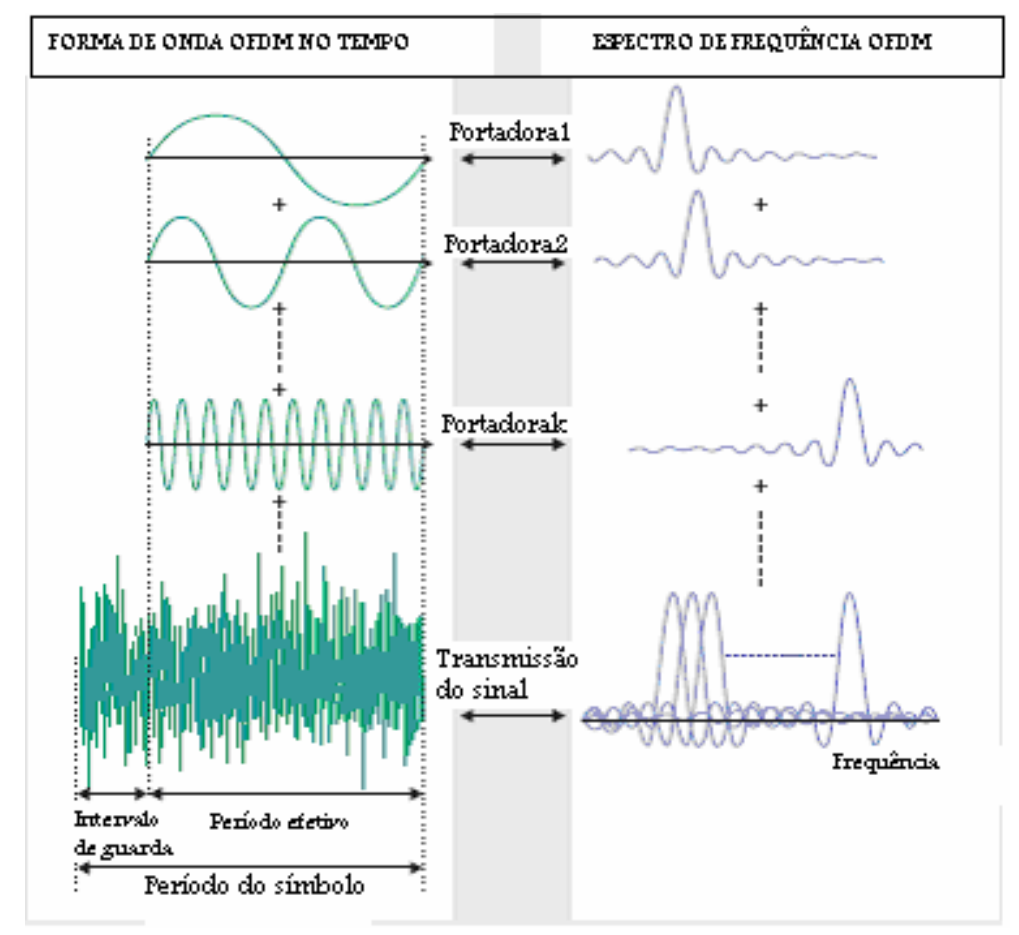

Figura 2.7: Espectros OFDM: domínio do tempo e domínio da frequiência.[28]

Além disso, a realização de uma transformada de Fourier neste sinal OFDM torna possível a determinação de informações de amplitude e de fase de cada portadora. Isto seria a demodulação do sinal OFDM. A modulação digital de cada portadora é normalmente realizada utilizando QPSK ou QAM. O QPSK e 16QAM são utilizados na transmissão por caminhos caracterizados por graves perturbações como nas comunicações móveis, quando automóveis e outros objetos estão presentes. Por outro lado, para recepção fixa, o 64QAM é utilizado para que o máximo de informações possíveis sejam transmitidas dentro de uma largura de banda limitada.

Os símbolos transmitidos em OFDM consistem de símbolos efetivos e intervalos de guarda. Os dados presentes nos portadores são transformados coletivamente através de uma transformada inversa discreta de Fourier em símbolos dentro do período efetivo do símbolo Tu. Um intervalo de guarda é formado por cada período do símbolo efetivo, tomando um pedaço dos dados do fim do símbolo em questão e simplesmente anexando-o à frente do símbolo, como mostra a Figura 2.8. A transmissão de símbolos no período $T_{u}+T_{g}$ é realizada dessa forma. 


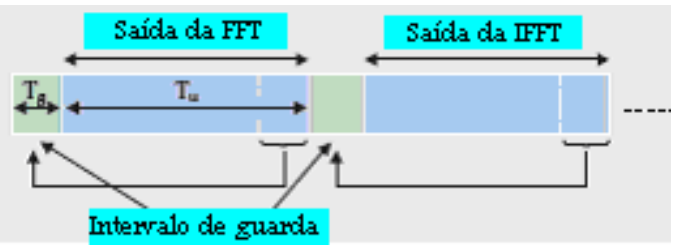

Figura 2.8: Intervalo de guarda.

O intervalo da portadora OFDM é o inverso do período da onda base (inverso do período do símbolo efetivo $\Delta \mathrm{f}=1 / \mathrm{Tu}$ ), mostrado na Figura 2.7. Por exemplo, para um período de símbolo efetivo $\mathrm{Tu}=1 \mathrm{~ms}$ o intervalo da portadora é $\Delta \mathrm{f}=1 \mathrm{kHz}$.

Cada subportadora OFDM tem uma pequena largura espectral por causa da baixa velocidade de modulação e o espectro OFDM transmitido, que agrupa estes espectros individuais, possui uma forma quase retangular, como mostrado na Figura 2.9.

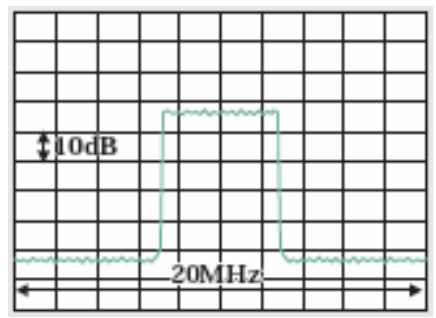

Figura 2.9: Espectro de transmissão OFDM

Se o número de portadoras $\mathrm{K}$ é grande, a banda ocupada $\mathrm{B}$ pode ser aproximado como $\mathrm{B}=\mathrm{K} \Delta \mathrm{f}$. Assumindo que $\mathrm{C}(1, \mathrm{k})$ é a informação transmitida correspondente ao símbolo $1 \mathrm{e}$ subportadora k, então o sinal OFDM S(t) pode ser expresso da seguinte forma:

$$
\begin{aligned}
& \mathrm{S}(\mathrm{t})=\operatorname{Re}\left\{e^{j 2 \pi f_{0} t} \sum_{j=-\infty}^{\infty} \sum_{k=0}^{k-1} C(l, k) \varphi(l, k, t)\right\} \\
& \varphi(l, k, t)=\left\{e^{j 2 \pi \frac{k-K t}{T_{u}}\left(j-T_{g}-l T_{s}\right)}, l T_{s} \leq t<(l+1) T_{s}\right. \\
& \varphi(l, k, t)=\left\{0, t<l T_{s}(l+1) T_{s} \leq t\right.
\end{aligned}
$$

onde, $\mathrm{k}$ é o número da subportadora; L é o número do símbolo; $\mathrm{K}$ é o número de subportadoras; $\mathrm{T}_{\mathrm{s}}$ é o período do símbolo $\left(\mathrm{T}_{\mathrm{g}}+\mathrm{T}_{\mathrm{u}}\right) ; \mathrm{T}_{\mathrm{g}}$ é o período do intervalo de guarda; $\mathrm{T}_{\mathrm{u}}$ é o período do símbolo efetivo; $\mathrm{F}_{\mathrm{c}}$ é a frequiência central do sinal $\mathrm{RF}$; Kc é o número 
correspondente da portadora que contém a freqüência central do sinal $\mathrm{RF}$; $\mathrm{C}(1, \mathrm{k})$ é a informação complexa transmitida correspondente ao símbolo 1 e subportadora $\mathrm{k} ; \mathrm{S}(\mathrm{t})$ é o sinal RF.

A modulação e demodulação dos sistemas OFDM podem ser realizadas para todas as subportadoras usando uma transformada inversa discreta de Fourier(IDFT, IFFT) e uma transformada discreta de Fourier(DFT, FFT). No lado do transmissor, o fluxo de bits transmitidos é a entrada de dados para a IFFT. Como exemplo, considere o caso da modulação 16QAM, Figura 2.10.

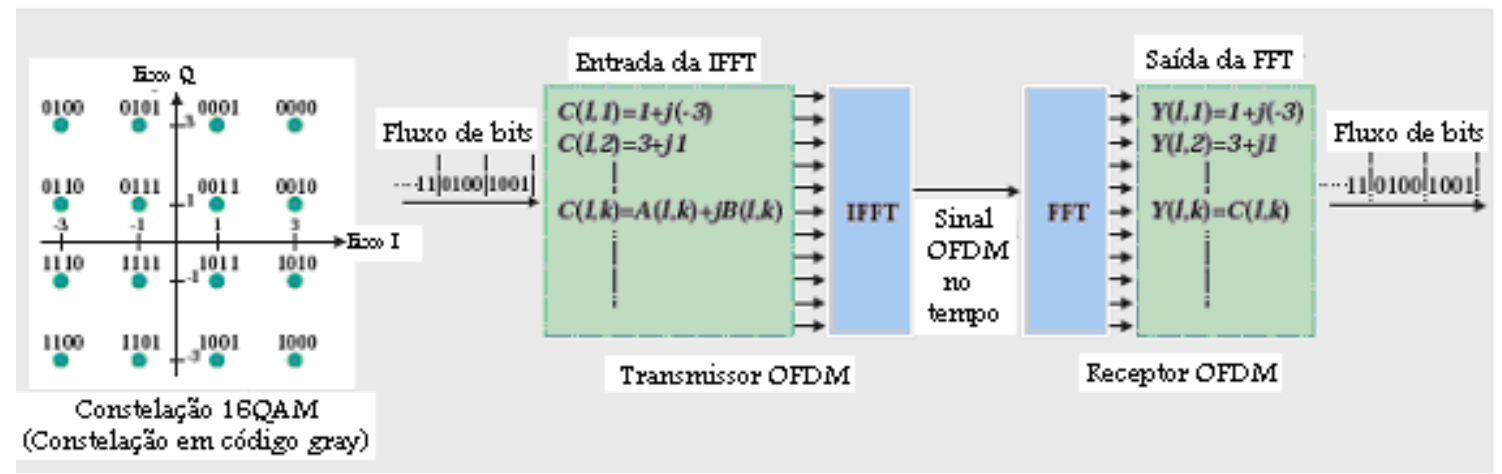

Figura 2.10: Transmissão de sinal 16QAM-OFDM.[28]

Aqui , cada portadora está dividida em 4 bits. Se os 4 bits atribuídos ao símbolo L e subportadora $\mathrm{k}$ forem 1001, então o valor do eixo I será 1 e o valor do eixo Q será -3 na constelação 16QAM. Por conseguinte, os dados C $(1, \mathrm{k})$ que entram na IFFT podem ser expressos como dados complexos da seguinte forma:]

$$
\begin{gathered}
\mathrm{C}(1, \mathrm{k})=\mathrm{A}(\mathrm{l}, \mathrm{k})+\mathrm{jB}(1, \mathrm{k}) \\
=1+\mathrm{j}(-3) \mathrm{c}
\end{gathered}
$$

Esta conversão da entrada de dados é realizada para as várias subportadoras e o resultado é submetido a IFFT (isto constitui o processo de modulação 16QAM-OFDM). A saída da IFFT passa a ser a informação de um símbolo na forma de onda temporal. No lado do receptor são realizadas as operações inversas às praticadas no lado do transmissor, para que assim possam ser recebidos os fluxos de bits (isto constitui o processo de demodulação 16QAM-OFDM). 
Usando apenas os processos acima descritos, porém, não resultam em um sinal OFDM $\mathrm{S}(\mathrm{t})$ transmissível e, no lado do receptor OFDM, a simples extração da saída da FFT não permite a recuperação do fluxo de bits originalmente transmitidos.

A geração de um sinal OFDM transmissível é mostrada na Figura 2.11.

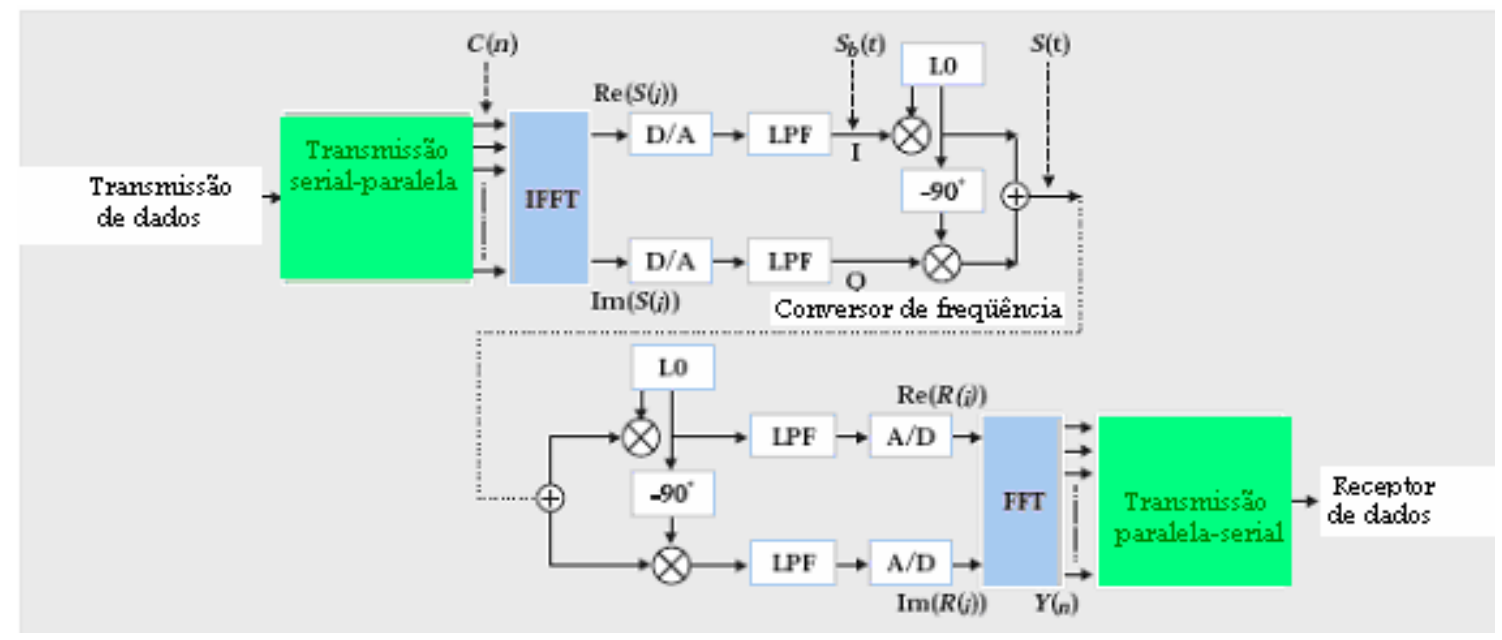

Figura 2.11: Sistema de transmissão/Recepção OFDM.[28]

Neste processo, o sistema transforma os dados (que estão na forma de números complexos) do domínio da frequiência para sinais no domínio do tempo, através de uma IFFT nos períodos dos símbolos. Esse sinais no domínio do tempo passam por conversores digital/analógico(D/A) e através de moduladores ortogonais passam da banda base para uma nova freqüência. $\mathrm{O}$ receptor neste sistema realiza o processo inverso, sendo realizada a conversão para a banda base e em seguida, utilizando um conversor analógico/digital, passa-se através de uma FFT e o sinal resultante é recuperado com as informações contidas em cada subportadora. 


\section{SISTEMA DRM}

\subsection{INTRODUÇÃO}

A formulação DRM se apóia em uma iniciativa mundial de trazer o rádio à era digital [5]. Esta iniciativa é realizada por um consórcio internacional, fundado em Março de 1998, o qual desenvolveu um padrão não privado para as transmissões nas freqüências inferiores a $30 \mathrm{MHz}$. Os membros são constituídos por empresas de radiodifusão, fabricantes de equipamentos, institutos de pesquisa, agências reguladoras e provedores de rede. $\mathrm{O}$ esforço conjunto resultou na publicação em Setembro de 2001 da norma ETSI e obteve aprovação pela UIT em Abril de 2001.

As ondas de banda longa, média e curta dão cobertura às grandes e remotas áreas, bem como à recepção domiciliar. Em associação a uma melhor qualidade e maior fidelidade de recepção de som semelhante ao analógico AM, bem como a possibilidade de serviço adicional de informação e dados, o DRM constitui padrão de elevado interesse de transmissão nacional e internacional.

A banda de transmissão das ondas longa, média e curta variam de 9 e $10 \mathrm{kHz}$. Uma taxa de dados de 20 a $24 \mathrm{kbit} / \mathrm{s}$ é necessária para a boa qualidade sonora. Isto resulta em uma largura de banda efetiva de pouco mais de $2 \mathrm{bit} / \mathrm{s} / \mathrm{Hz}$. Com esses números pode-se deduzir, considerando também um canal codificador e sinalizador sobrecarregado, que 6 bits por símbolo de modulação são razoáveis, resultando em uma modulação 64-QAM. Em combinação com canais de ondas curtas que sofrem por alta dispersão Doppler e atraso na propagação, o sistema desenhado recebe uma tarefa difícil.

Para tornar o projeto do sistema compreensível, bem como para apresentar os algoritmos do receptor, o texto está organizado seguindo o fluxo do sinal de entrada do receptor ao fluxo de saída do áudio. No início, a Seção 3.2 descreve as mais importantes razões do porque o DRM é mais vantajoso em relação ao analógico AM. Os requisitos para o desenvolvimento do sistema e uma visão geral do sistema são apresentados na secção 3.3. As bases para o projeto de cada sistema é o canal de transmissão, que é explicado na Secção 3.4. A descrição mais detalhada do sistema começa na Secção 3.5 explicando os 
diferentes canais lógicos utilizados no sinal multiplexador. A seção 3.6 descreve como o sinal é construído e explica os quatro modos de robustez adequados para as diferentes condições de transmissão. As Seções 3.7 e 3.8 dão informações acerca da sincronização e estratégias para estimação do canal necessário no receptor. As últimas duas seções 3.9 e 3.10 tratam da codificação do canal e codificação da fonte e sua adaptação para o DRM.

\subsection{VANTAGENS DO DRM EM COMPARAÇÃO COM O AM}

O analógico AM sofre de má qualidade de áudio e recepção. Isso abre a possibilidade de enormes melhorias com um esquema de transmissão digital. Suas principais vantagens são explicadas a seguir:

Robustez nos canais com desvanecimento. No analógico AM todos os distúrbios como perdas devido a multipercursos, ruído, bem como interferências de canais adjacentes e coadjacentes causam prejuízo no áudio. Um sistema digital bem concebido pode lidar muito melhor com estas perturbações.

Melhor qualidade de áudio. A banda de áudio no DSB(Double Sideband) AM é inferior à metade da largura da banda da transmissão. Considerando filtros adicionais no receptor, uma largura de banda de áudio de $2,4 \mathrm{kHz}$ é típica. Os algoritmos usados no DRM supera esta limitação e fornece uma boa qualidade de som na taxa de bit disponível.

Economia de potência no lado de transmissão. Quando usado o DSB AM, a maior parte da potência de transmissão está na portadora. No caso DRM, enorme economia de potência é conseguida na transmissão, para manter a mesma área de cobertura.

Serviços de informação relacionados. Alguns anos atrás, foi tentado estabelecer um AMDS (sistema de dados de transmissão sonora monofônica AM) que falhou. A capacidade no DRM para serviços relacionados aos dados são muito mais elevadas, resultando em facilidade na utilização de rádios.

Serviços de dados. Além de serviços de dados, de programas de áudio e texto informativo, fotos também são possíveis de serem transmitidas. 


\subsection{VISÃO GERAL DO SISTEMA}

\section{A:Requisitos para desenvolvimento do sistema}

A fim de permitir o êxito no mercado, uma série de requisitos devem ser cumpridos. A maioria deles foi aprovada pela ITU e cuidadosamente analisada quanto ao desenvolvimento da especificação do sistema. O sistema é totalmente compatível com o espaçamento do canal da ITU e largura de banda da RF. Na onda média, a grade do canal nas regiões ITU 1 e 3 é de $9 \mathrm{KHz}$, na região 2 é de $10 \mathrm{KHz}$, enquanto na onda curta o espaçamento é de $5 \mathrm{KHz}$ com $10 \mathrm{KHz}$ de largura de banda.

Para manter o investimento por radiodifusores, os transmissores modernos existentes são re-utilizáveis e expansíveis com os moduladores digitais. Deve ser possível construir receptores de baixo custo com baixo poder de consumo para permitir uma rápida penetração no mercado mundial. A complexidade do sistema, portanto, é um importante fator.

\section{Características adicionais são empregadas para facilitar a introdução do sistema}

\section{DRM:}

Redes de freqüência única(SFN) são uma importante característica nos sistemas de transmissão digital para alcançar uma elevada eficiência de espectro.

É possível a transmissão do sinal analógico e digital, simultaneamente, o que significa que os sinais digital e analógico partilham um canal com largura de banda de 9 ou $10 \mathrm{KHz}$.

Para a transição gradual do AM para a digital, um cenário multcast também é viável. Multicast significa que o sinal analógico e o digital ocupam seus próprios canais adjacentes separados transmitidos da mesma estação.

\section{B. Parâmetros do sistema}

Os diferentes modos de transmissão permitem às emissoras, com obstáculos no canal de transmissão, condições de propagação. Além da largura de banda nominal de 9/10 kHz, o sistema suporta também modos de meio canal $(4,5$ e $5 \mathrm{kHz})$ a fim de permitir transmissão simultânea com a analógica AM, bem como modos de duplo canal (18 e $20 \mathrm{kHz}$ ). A troca de capacidade e robustez, multipercurso e dispersão Doppler, pode ser definida pela constelação, taxa de código e modo OFDM. Considerando todos os parâmetros, uma típica 
taxa de dados em canais de 9/10 kHz são de 20-24 kbit/s, a taxa máxima em 20 kHz é de 72 $\mathrm{kbit} / \mathrm{s}$.

\section{Arquitetura do sistema.}

O sistema DRM é esboçado na Figura 3.1, a qual descreve o fluxo geral de informação. Até quatro áudios ou serviços de dados são codificados ou pré-codificados na fonte. Para adaptação à capacidade do sistema e ao conteúdo do programa (áudio ou discurso), diferentes codificadores de áudio, chamados AAC, CELP e HVXC, estão disponíveis. Eles estão todos incluídos no padrão MPEG-4. Para atingir a qualidade sonora semelhante à FM, a AAC é prolongada pela SBR (Replicador espectral de Banda), uma ferramenta amplificadora que utiliza informação do envelope espectral do sinal de áudio para aumentar a largura da banda de áudio.

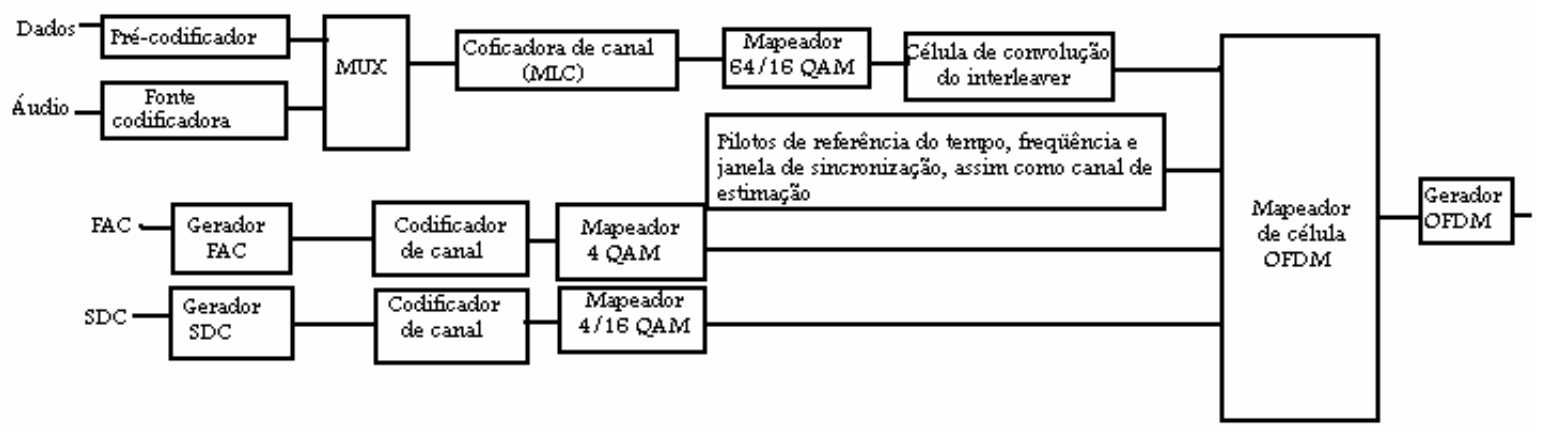

Figura 3.1: Sistema DRM

Os dois canais de informação FAC (canal de acesso rápido) e SDC (Serviço de descrição do canal) carregam informações sobre a configuração, que orienta o receptor para decodificar o sinal, bem como informações de serviços como freqüências alternativas.

Para uma codificação de canal, um esquema MLC é usado em combinação com modulação 16 ou 64 -QAM e dois níveis diferentes para o interleaver. Proteção Desigual de erro (UEP) e modulação hierárquica são suportados. Causados por condições diferentes de propagação em todas as freqüências abaixo de $30 \mathrm{MHz}$, quatro modos diferentes de OFDM são suportados. 
Para o receptor, o sinal flutuante tem de ser espelhado como mostrado na Figura 3.2. Alguns dos algoritmos de sincronização trabalham no tempo e outros no domínio da frequiência. Estimação de canal é também realizada após a demodulação OFDM. Decodificação de canal e decodificação da fonte são feitos com o sinal equivalente.

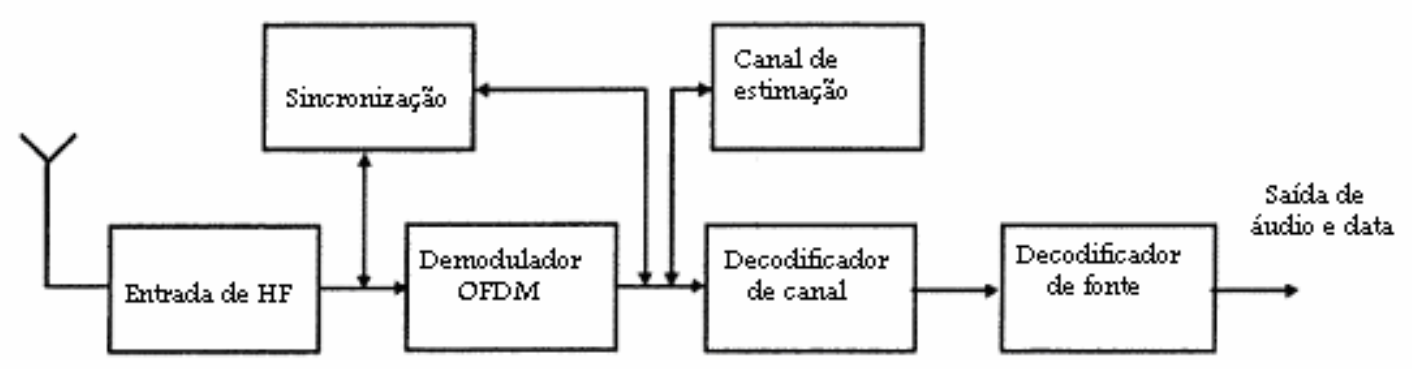

Figura 3.2: Estrutura de um receptor DRM

\subsection{CANAL DE TRANSMISSÃO}

Como o DRM será aplicado na banda AM, as freqüências AM utilizadas para transmissão contêm:

1- banda de freqüência baixa (LF, ondas longas) de 148,5 a $283.5 \mathrm{kHz}$, na região ITU 1 somente;

2- banda de freqüência média (MF, onda médio) de 526.5 para $1606.5 \mathrm{kHz}$ nas regiões ITU 1 e 2 e de 525 a 1705 kHz na região ITU 2;

3- bandas de freqüência alta freqüência (HF, onda curta) de 2,3 MHz a $27 \mathrm{MHz}$ em nível mundial.

Nessas bandas de transmissão, dois modos de propagação predominam: as ondas terrestre e ionosférica. Em ondas médias e longas pode-se observar muitas vezes somente propagação de onda terrestre que pode ser modelada segundo o modelo AWGN (ruído gaussiano branco aditivo). Em ondas curtas, no entanto, reflexões na ionosfera ocorrem. A ionosfera é composta de várias camadas (D, E, F), que refletem, absorvem ou atenuam ondas dependendo de seu comprimento de onda. A estrutura da ionosfera varia muito sobre a superfície terrestre. Há também uma dependência da época e atividade solar. Se a onda 
também está refletida na superfície da Terra, várias reflexões podem ocorrer como mostrado na figura 3.3 resultando em um canal de multipercurso.

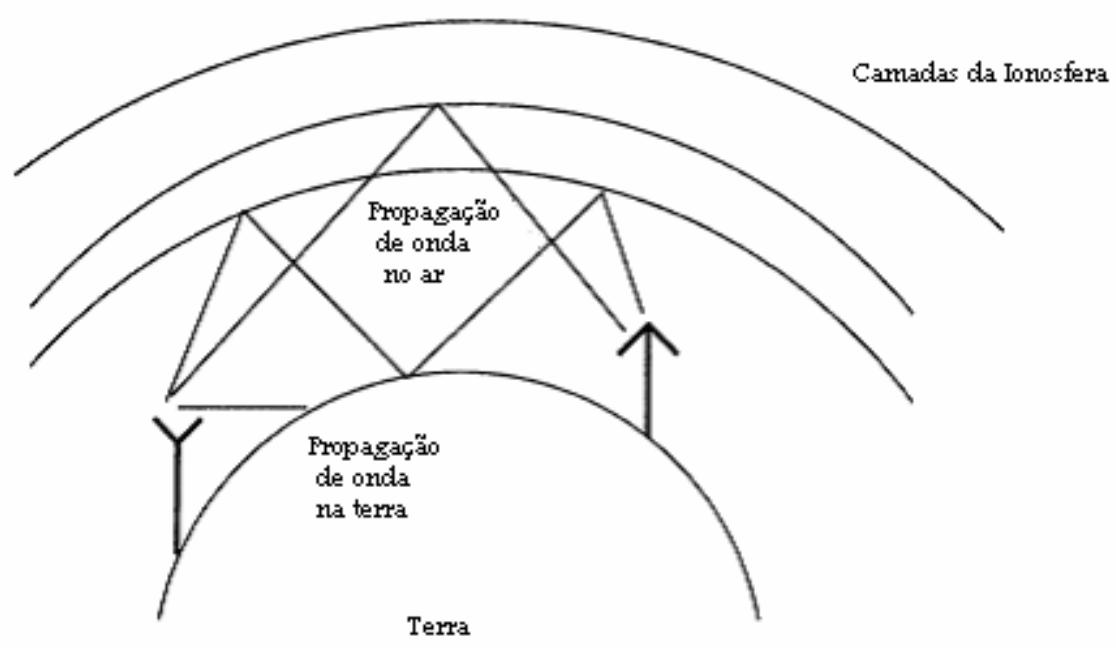

Figura 3.3: Propagação de ondas nas bandas AM

O movimento das camadas ionosféricas causa o efeito Doppler do sinal. Observações mostraram que a forma Gaussiana para o efeito Doppler para HF é uma boa aproximação.

\subsection{MULTIPLEXAÇÃO}

A multiplexação DRM tem de cumprir requisitos diferentes. Por um lado, uma seleção de serviço rápido em toda a gama de freqüência deve ser possível, por outro lado, uma grande quantidade de informações associadas com o programa tem de ser transmitida. Conseqüentemente três canais lógicos são introduzidos na multiplexação. O Canal de Serviço Principal (MSC), o Canal de Descrição do serviço (SDC) e o Canal de Acesso Rápido (FAC).

\section{A. Canal de Serviço Principal}

O MSC tem a maior capacidade e contém os dados de no máximo quatro ondas com áudio ou conteúdo de dados. Os serviços (programas de áudio e aplicativos de dados) são mapeados para estas ondas.

\section{B. Canal de Acesso Rápido}


O FAC contém todas as informações que sejam úteis para a seleção de serviço quando o receptor varre as bandas de freqüência. As duas partes da FAC consistem de parâmetros de canal, como ocupação de espectro e a constelação da modulação, e parâmetros de serviço, como um serviço identificador de 24 bits. O FAC com transmissão dentro de uma janela (400 ms) é constituído de 64 bits, incluindo os parâmetros de canal e os parâmetros de serviço.

\section{Canal de Descrição do Serviço}

O SDC inclui as informações de como o MSC tem de ser decodificado, bem como os atributos do serviço. Estes atributos consistem em freqüências alternativas, rótulo de serviço, cronograma de freqüência, etc. A capacidade da SDC é dependente de diferentes parâmetros como ocupação espectral e modalidade de robustez. O conteúdo da SDC dividese em entidades de dados com tamanho variável.

\subsection{ESTRUTURA DE TRANSMISSÃO}

O sistema DRM baseia-se na técnica de transmissão OFDM. A principal estrutura de um transmissor OFDM é mostrada na figura 3.4. Um sinal OFDM é constituído por uma soma de subportadoras que são moduladas usando PSK ou QAM. Cada subportadora é espaçada pela distância de freqüência $\Delta \mathrm{F}$. Considerando o sinal transmitido OFDM dentro da largura de banda de $\mathrm{B}=\mathrm{N} \Delta \mathrm{F}$ e usando o teorema de amostragem, o sinal transmitido OFDM deve ser amostrado com o tempo de amostragem $\mathrm{t}_{\mathrm{s}}=1 / \mathrm{B}$. Isto leva a uma duração de símbolo

OFDM $\mathrm{T}_{\mathrm{u}}=\mathrm{N} \Delta \mathrm{t}=1 / \Delta \mathrm{F}$. A amostra dos sinais de transmissão discretos no tempo $\mathrm{S}_{\mathrm{n}, \mathrm{i}}$ é calculada da seguinte forma:

$$
\begin{aligned}
& \mathrm{S}_{\mathrm{n}, \mathrm{i}}=\frac{1}{\mathrm{~N}} \sum_{k=0}^{N-1} S_{n, k} e^{j(2 \pi / N) i k} \operatorname{com}-\infty<n<\infty ; \\
& 0 \leq i \leq N-1
\end{aligned}
$$


onde $\mathrm{S}_{\mathrm{n}, \mathrm{k}}$ são os símbolos de modulação da subportadora dentro de um único bloco OFDM. Saliente-se que o sinal OFDM complexo de banda base $S_{n, i}$ é na verdade a transformada inversa discreta de Fourier (IDFT) de $\mathrm{N}$ símbolos de entrada $\mathrm{S}_{\mathrm{n}, \mathrm{k}}$.

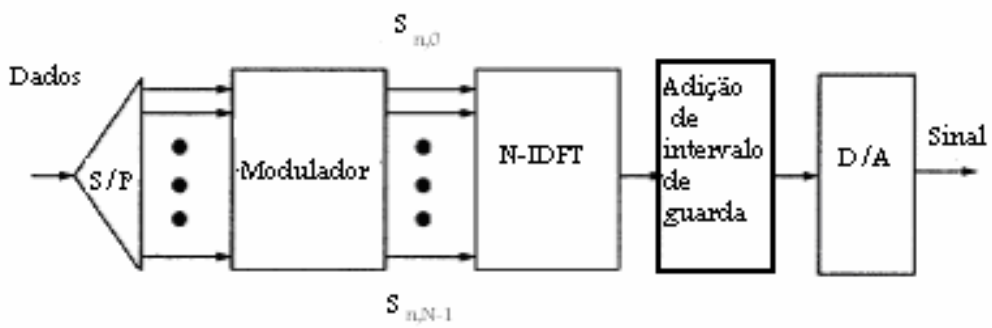

Figura 3.4: Estrutura de um transmissor OFDM

A fim de evitar distorções de canais de multipercurso, o sinal OFDM é ciclicamente prorrogado por um período de guarda $\mathrm{T}_{\mathrm{g}}$. Como resultado, sinais de multipercurso com atrasos menores do que os tempos de guarda não podem causar ISI (interferência entre símbolo).

Devido às difíceis condições de propagação em bandas de freqüência inferior a $30 \mathrm{MHz}$ um conjunto de diferentes modos OFDM é especificado, a fim de lidar com os diferentes canais de transmissão. Os parâmetros do símbolo OFDM relacionados são apresentados na Tabela 3.1. Verifica - se que apenas para o modo B da IDFT pode ser substituída por uma potência clássica de 2 FFT . Para todos os outros modos um primeiro fator FFT é usado.

Modos de Tramissão DRM

\begin{tabular}{l|r|r|r|r}
\hline \multirow{2}{*}{ Parâmetros } & \multicolumn{4}{|l}{ Modo DRM } \\
\cline { 2 - 5 } & $\mathrm{A}$ & $\mathrm{B}$ & $\mathrm{C}$ & $\mathrm{D}$ \\
\hline $\mathrm{Tu}(\mathrm{ms})$ & 24 & $211 / 3$ & $142 / 3$ & $91 / 3$ \\
\hline $\mathrm{Tg}(\mathrm{ms})$ & $22 / 3$ & $51 / 3$ & $51 / 3$ & $71 / 3$ \\
\hline FFT tamanho N & 288 & 256 & 176 & 112 \\
\hline $\begin{array}{l}\text { Uso das portadoras } \\
\text { (no canal de 10 kHz) }\end{array}$ & 226 & 206 & 138 & 88 \\
\hline
\end{tabular}

Tabela 3.1: Modos de transmissão DRM 
Os diferentes modos OFDM variam em espécie de robustez. A modalidade A é aplicada para transmissões em canais Gaussianos ou canais com menor falha, que são típicas para transmissões de ondas na terra (ondas médias, ondas longas). Os outros modos podem suportar todos com mais tempo e freqüência seletiva de canais, que são típicas de transmissões de ondas no ar (ondas curtas e ondas médias à noite). Comparando o modo C com o modo B, pode-se afirmar que ambos têm a mesma robustez contra o atraso de propagação devido ao seu idêntico comprimento de intervalo de guarda, mas o modo C, tem uma maior robustez contra a propagação Doppler por causa de um menor $\mathrm{T}_{\mathrm{u}}$. Naturalmente que, para uma determinada banda B, a possível taxa de dados com o modo C é inferior à taxa possível de dados com modo B. Modo D tem o maior tempo de guarda e o menor comprimento de símbolo útil $\mathrm{T}_{\mathrm{u}}$. Portanto o modo $\mathrm{D}$ tem a maior robustez contra grave atraso e propagação Doppler de todos os modos DRM para o preço da menor taxa de dados de todos os modos DRM. A escolha do melhor modo é uma questão importante para os radiodifursores. Em comparação com outras aplicações de radiodifusão, que também usa o princípio OFDM como DAB e DVB-T, pode-se afirmar que para o DRM o número de subportadoras é baixo. Como conseqüência do canal de banda limitada o espaçamento da subportadora equivale à cerca de apenas $50 \mathrm{~Hz}$, enquanto que o DAB e DVB-T têm o espaçamento da subporatadora no intervalo de $\mathrm{kHz}$. O baixo espaçamento da subportadora corresponde a uma duração relativamente grande do símbolo OFDM (no intervalo de vários ms). Considerando que os mais comuns sistemas OFDM o tempo de guarda é escolhida para ser $\mathrm{T}_{\mathrm{g}} \leq \mathrm{T}_{\mathrm{u}} / 4$, o modo $\mathrm{D}$, muito robusto, é caracterizado com um grande intervalo de guarda de quase a duração do símbolo útil $\mathrm{T}_{\mathrm{u}}$.

A figura 3.5 explica a estrutura de janela da transmissão DRM. Nela pode ser visto que cada super janela da transmissão consiste em três janelas de transmissão. Cada janela de transmissão consiste de $\mathrm{N}_{\mathrm{s}}$ símbolos OFDM. Para o modo $\mathrm{A}$ e $\mathrm{B}, \mathrm{N}_{\mathrm{s}}=15$, para o modo $\mathrm{C}$, $\mathrm{N}_{\mathrm{s}}=20$ e para o modo $\mathrm{D}, \mathrm{N}_{\mathrm{s}}=24$. É importante notar que todos símbolos OFDM sempre contêm dados e informações de referência. A completa referência de símbolo OFDM como na DAB não está disponível. Mais detalhadamente, uma janela de transmissão OFDM contém células de dados, de controle e de piloto. As células de controle consiste do FAC e SDC, conforme descrito na seção 3.5. A SDC é repetida a cada super quadro de transmissão. 


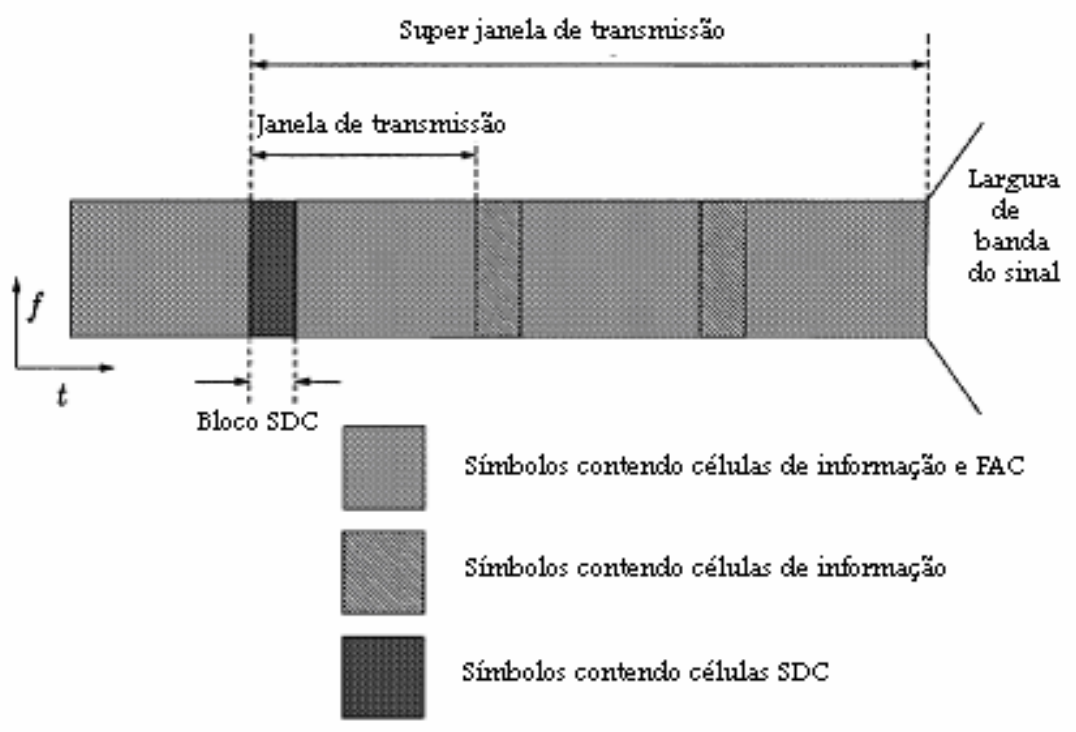

Figura 3.5: Formato da janela de transmissão DRM

O objetivo das células piloto é duplo: por um lado, podem ser utilizados para a janela de transmissão, freqüência e tempo de sincronização. Por outro lado, eles são usados para estimativa de canal. Aqui queremos apenas descrever a estrutura das células piloto. Posteriormente seré descrito, como as células piloto podem ser exploradas para as diferentes tarefas de sincronizações e de estimativa de canal. O sistema DRM distingue três tipos de células piloto: célula de referência de freqüência, célula de referência de tempo e célula de referência de ganho.

As células de referência de frequiência são tons de piloto de fase contínuas, que estão sempre presentes durante as transmissões em sinal DRM em certas subportadoras. O espaçamento de freqüência entre a portadora DC e as correspondentes frequiências de referência igual a 750, 2250 e $3000 \mathrm{~Hz}$, respectivamente. Se essas células são exploradas para estimação de frequiência, a unidade de estimação de freqüência pode ser um modo independente de implementação.

As células de referência do tempo estão localizadas apenas no primeiro símbolo OFDM de cada janela de transmissão. Sua principal finalidade é a de conseguir uma sincronização de janela de transmissão fiável. Além disso, também pode ser usado para detecção de frequiência de offset. 
A maior quantidade de células piloto são as células de referência de ganho. Estas células piloto estão espalhadas igualmente no tempo e direção de freqüência. A figura 3.6 ilustra a malha de frequiência do tempo para o modo B.

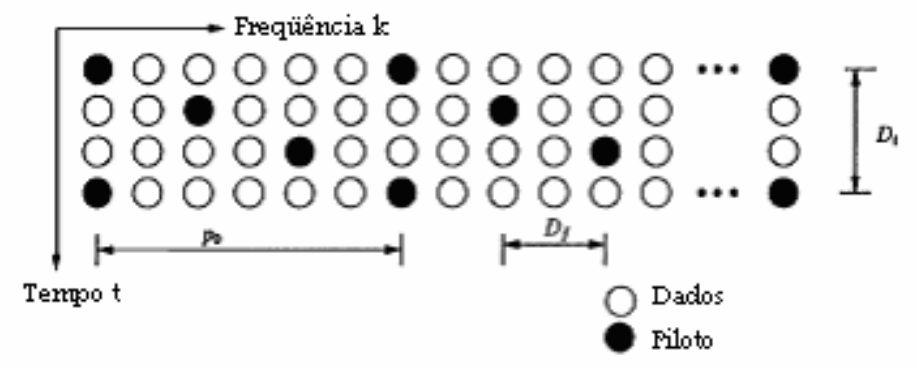

figura 3.6: Padrão piloto para o modo B do DRM

As células de referência de ganho são usadas principalmente para obter uma estimativa correta da função de transferência do canal. Como DRM é um sistema de transmissão OFDM coerente, uma estimativa da função de transferência do canal é necessária para uma demodulação coerente. Da teoria, é evidente que o número de células piloto, que são necessárias para a estimativa do canal, depende fortemente da propagação Doppler esperada e atraso de propagação. Portanto a distância de frequiência entre duas células piloto vizinhas em um símbolo OFDM está correlacionada com a robustez de cada modo de transmissão.

\subsection{SINCRONIZAÇÃO}

A primeira tarefa de sincronização do processo é conseguir uma sincronização grosseira do tempo. É comumente conhecido que uma escolha errada da janela de demodulação DFT pode levar a forte ISI (interferência entre símbolos) e tem um grande impacto sobre todos os algoritmos pós DFT (por exemplo, a estimativa do canal).

A sincronização de freqüência é a próxima questão importante. O offset de freqüência entre o sinal transmitido e o sinal recebido pode ser introduzida por imprecisões do oscilador local do receptor ou pelo canal de transmissão. A freqüência de offset pode ser dividida em uma parte integrante do espaçamento da subportadora e uma parte fracionária. A estratégia da sincronização de freqüência é estabelecer a ortogonalidade da subportadora 
tão rápido e com a maior precisão possível (aquisição) e, em seguida, manter ortogonalidade (acompanhamento).

$\mathrm{Na}$ próxima etapa as amostras do sinal recebido são corrigidas. A freqüência de offset inteira pode ser estimada usando as células de referência do tempo em todas os primeiros símbolos OFDM de uma janela e algumas células piloto vizinhas no mesmo símbolo. Deve-se mencionar que as três fases contínuas de referência da freqüência também poderiam ser usadas para a sincronização de freqüência. Neste caso, o receptor pesquisa somente para as posições de frequiência dos três tons no sinal recebido e compara o resultado com as posições esperadas das referências de frequiência. Mas, devido à grave freqüência de canais seletivos (que é um caso normal em onda curta) essas referências de freqüência poderiam ser fortemente danificadas, de modo que a freqüência de sincronização confiando somente em três referências de freqüência pode falhar e poderia atrasar todo o processo de sincronização.

Após finalizar a fase de aquisição, o receptor muda para a fase de monitoramento. A fase de monitoramento pode ser separada em uma fase de monitoramento do tempo e uma fase de monitoramento da freqüência. Sincronização fina do tempo pode ser conseguida através de uma estimativa da CIR (resposta de impulso do canal). O método ótimo para a sincronização fina do tempo é maximizar a energia do CIR dentro de uma janela para todas as possíveis posições de ensaio.

\subsection{ESTIMAÇÃO DE CANAL}

Modulação coerente demanda estimativa de canal no receptor para fazer possível a equalização do canal. Estimativa de canal pode ser feita em freqüência, bem como no domínio do tempo onde o segundo método é freqüentemente chamado de estimador baseado na DFT. Ambos os métodos têm em comum que eles estimam a função de transferência. Para implementações práticas os três critérios principais são desempenho, a complexidade do algoritmo e o consequiente atraso no receptor. O último ponto é o responsável pelas limitadas possibilidades de filtragem na direção do tempo. 
Os estimadores no domínio da freqüência são mais comuns devido à disponibilidade do sinal no domínio da frequiência, assim não é necessária uma transformação extra. Um conhecido representante é o filtro Wiener, que é bom, em termos de MSE (erro médio quadrado).

Estimadores do domínio do tempo transformam as observações do ruído do domínio da freqüência no domínio do tempo por uma IDFT. Consequentemente, o fato do canal de alimentação no domínio do tempo estar concentrado em poucos números de amostras, ele pode ser usado. O MSE dos dois diferentes métodos são ilustrados na figura 3.7 para um casal de portadoras OFDM.

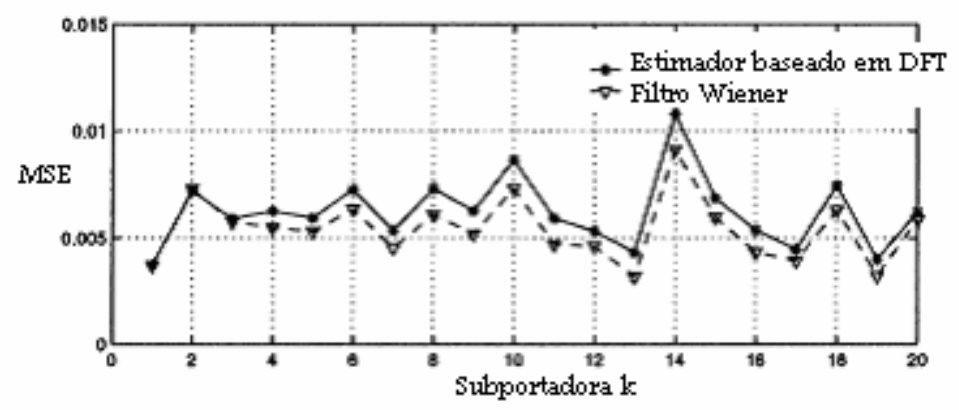

Figura 3.7: Comparação do MSE entre o filtro Wiener e o estimador baseado na DFT.

\subsection{CÓDIGO E MODULAÇÃO DO CANAL}

O esquema de MLC (codificação multinível) é usado no DRM para que seja obtida uma transmissão com desempenho ótimo. A meta é o desenvolvimento de uma BER menor que $10^{-4}$ exigido pelo decodificador para conseguir um áudio quase sem distorções. Este objetivo tem de ser alcançado com um decodificador de baixa complexidade e baixos valores de SNR.

Características adicionais como UEP (proteção de erro desigual) e modulação hierárquica são necessárias. As maiores e menores partes protegidas pelo UEP podem ser utilizadas de uma forma flexível para alcançar um elevado grau de liberdade quando atribuído as duas partes dos multiplexadores. 
Isso significa que diferentes proteções podem ser alcançadas dentro de um serviço, bem como entre os diferentes serviços.

Para combater os erros de transmissão e também falhas de canais uma célula Interleaver para o MSC é adicionada, com a possibilidade de escolha de duas diferentes profundidades além dos bits de interleaver da figura 3.8.

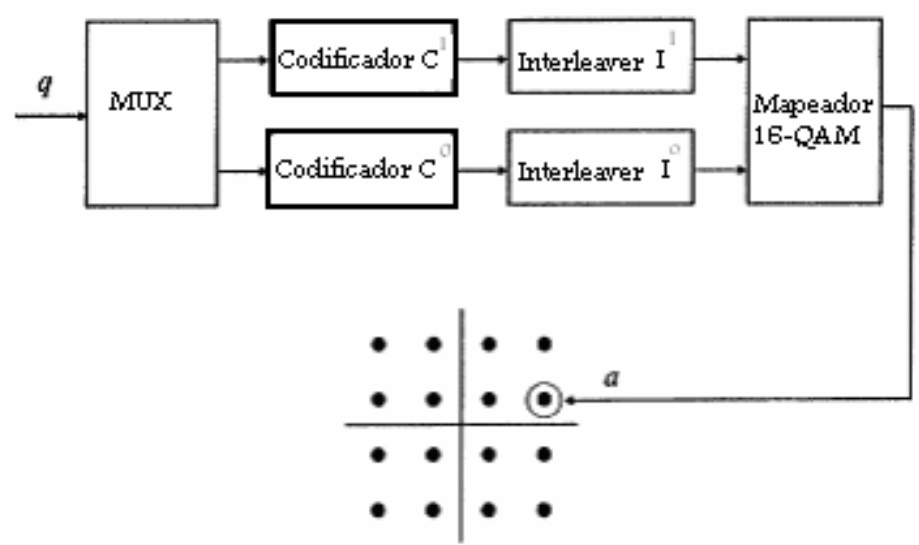

Figura 3.8: Codificação multinível para 16-QAM.

Dependendo do tempo de seletividade do canal, baixo ou alto, um interleaving pode ser escolhido com um atraso global de aproximadamente 0.8 ou 2.4 segundos. Uma dispersão de energia é utilizada para evitar indesejáveis regularidades no sinal transmitido. Portanto o sinal é codificado por um módulo 2 além de um PRBS (sequiência binária aleatória). Os diferentes canais lógicos requerem diferente robustez resultando em várias constelações e taxas de código, tal como apresentado no tabela IV. Além disso, a combinação da constelação e da taxa de código proporciona um elevado grau de flexibilidade ao longo de um vasto leque de canais transmissão. 
CONSTHA ÇÃo DRM E TAXa DE CÓDigo

\begin{tabular}{|c|c|c|}
\hline CAMAL & CONSTEIAÇÃo & TAXA DE CÓDIGO \\
\hline FAC & 4-QAM & 0.6 \\
\hline SDC & 4-/16-QAM & 0.5 \\
\hline MSC & $\begin{array}{l}16- \\
\text { QAM }\end{array}$ & $\begin{array}{l}0.5 / 0.62 \quad(16-\mathrm{QAM}) \\
0.5 / 0.6 / 0.71 / 0.78 \\
(64-\mathrm{QAM})\end{array}$ \\
\hline
\end{tabular}

Tabela 3.2: Constelações e taxas de código.

MLC é um poderoso esquema de modulação codificada. O núcleo do MLC é que erros mais propensos das posições dos bits no mapeamento QAM obtêm uma maior proteção na codificação do canal. Considerando por exemplo o 16-QAM dividido em seus componentes em quadratura resulta em dois 4-ASKs, o esquema MLC necessita de dois codificadores em paralelo com duas taxas de código diferentes conforme descrito na Figura 3.8. Esta consideração unidimensional do espaço do sinal facilita bastante os requisitos de um projeto MLC.

\subsection{CÓDIGO DE ÁUDIO}

Desde que a taxa típica de dados esteja entre $9 / 10 \mathrm{kHz}$, os canais entre 20 e $24 \mathrm{kbit} / \mathrm{s}$, a eficiência do código da fonte codificadora têm de ser muito elevado para obter uma boa qualidade de áudio.

O segundo requisito para as fontes codificadoras é que elas têm que trabalhar em canais propensos a erro, devido ao fato de que o sistema de comunicação móvel nunca obtém transmissões livres de erro. Baseado em vários testes de escuta dentro do consórcio DRM, em parte realizada em conjunto com MPEG, foram escolhidos algorítmos de código de fala e de áudio. Estes algoritmos são todos parte do padrão MPEG-4, o ACC (código avançado de áudio), CELP (Predição linear de código excitado) e HVXC (código de excitação com vetor harmônico). AAC é um código de áudio genérico que trabalha em uma ampla gama 
de taxas de bits, enquanto que os outros dois são codificadores de fala naturalmente adequados para baixa e ultra baixa taxa de bits.

Os algoritmos de codificação de discurso e áudio seguem princípios diferentes. Codificadores de áudio perceptual chegam a reduzir irrelevância e redundância, com a ajuda de um modelo acústico. Assim, apenas as partes relevantes do sinal são transmitidas. O diagrama de blocos do decodificador é desenhado na Figura 3.9.

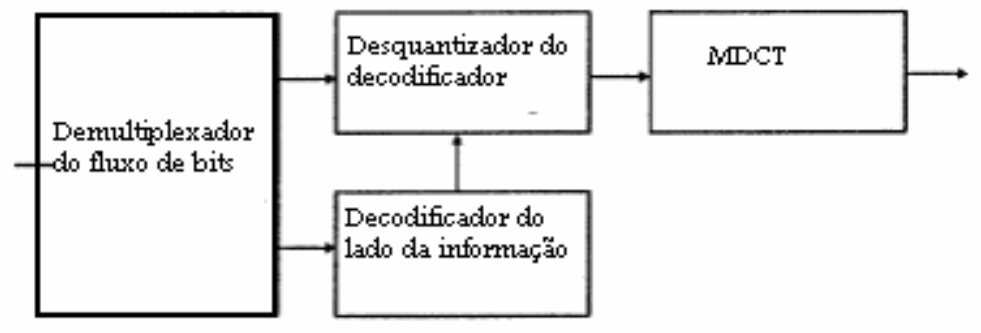

Figura 3.9: Princípio de um decodificador de áudio.

Após demultiplexar, o bitstream é desquantizado de acordo com o conteúdo das informações secundárias. O MDCT (transformada discreta modificada do co-seno) fornece resolução de alta frequiência, resultando em alta eficiência de codificação para componentes tonais e harmônicos do sinal. Para sinais críticos no domínio do tempo partes da ferramenta TNS (forma de ruído temporal) são capazes de moldar a quantização do erro no domínio do tempo sem alterar a resolução da freqüência.

Para os algoritmos de códigos de discurso, o trato vocal humano é simulado por um gerador de excitação e uma síntese de banco de filtro. Figura 3.10 ilustra o decodificador de discurso.

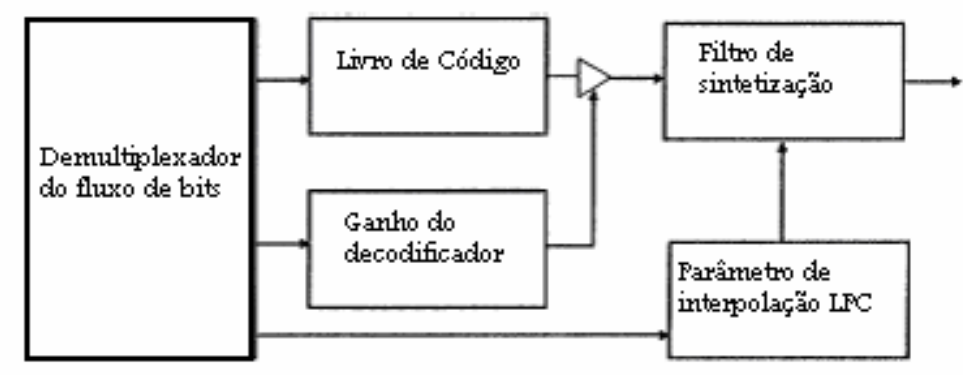

Figura 3.10: Principio de um decodificador de discurso. 
O envelope de espectro do sinal é descrito com parâmetros LPC (Código de Predição Linear).O gerador de excitação consiste no livro de códigos, contendo componentes de sinal periódicos e aleatórios. Ambos podem ser amplificados independente por fatores de ganho. Filtros de síntese formam o sinal de saída.

AAC foi desenvolvido dentro da MPEG-2 para melhorar a eficiência de compressão de seus algoritmos antecessores e para habilitar várias taxas de bits e amostragem. Desde que a boa tecnologia AAC tornou-se parte do MPEG-4, novas funcionalidades como codificação robusta de erro foram possíveis. Esse formato especifica uma nova sintaxe de fluxo de bits, oferecendo maior resistência em caso de canais propensos a erro. Em associação com UEP, como é explicado na Secção 3.9, a degradação também é atingida. Para atingir o alinhamento com a transmissão de quadros DRM de $400 \mathrm{~ms}$, como é explicado na Secção $\mathrm{V}$, uma transformação no comprimento é usada, o que corresponde a janelas de áudio de $80 \mathrm{~ms}\left(\mathrm{f}_{\mathrm{sa}}=12 \mathrm{kHz}\right)$ e $40 \mathrm{~ms}\left(\mathrm{f}_{\mathrm{sa}}=24 \mathrm{kHz}\right)$,respectivamente.

Considerando 5 ou 10 janelas de áudio com comprimento de bits variável, um bloco com comprimento fixo é construído, chamado de janela de super-áudio. Conseqüentemente nenhuma sincronização adicional é necessária para a codificação de áudio. AAC suporta estéreo genérico, mono e estéreo comum.

Além disso, a ferramenta SBR (replicação de banda espectral) é usada para aumentar a banda de código de áudio para mais de $15 \mathrm{kHz}$. O conceito utiliza o efeito onde a série harmônica do sinal de áudio, com código truncado, pode ser estendido baseado na relação entre componentes de banda baixa e alta. Assim, apenas informações no espectro de banda alta tem que ser transmitidas para reconstruir a banda alta no descodificador. AAC e CELP podem tirar proveito do SBR em baixas taxas de bits.

O código de discurso em MPEG CELP é oferecido para permitir razoável qualidade do discurso com baixas taxas de bits. Ver tabela 3.3. 


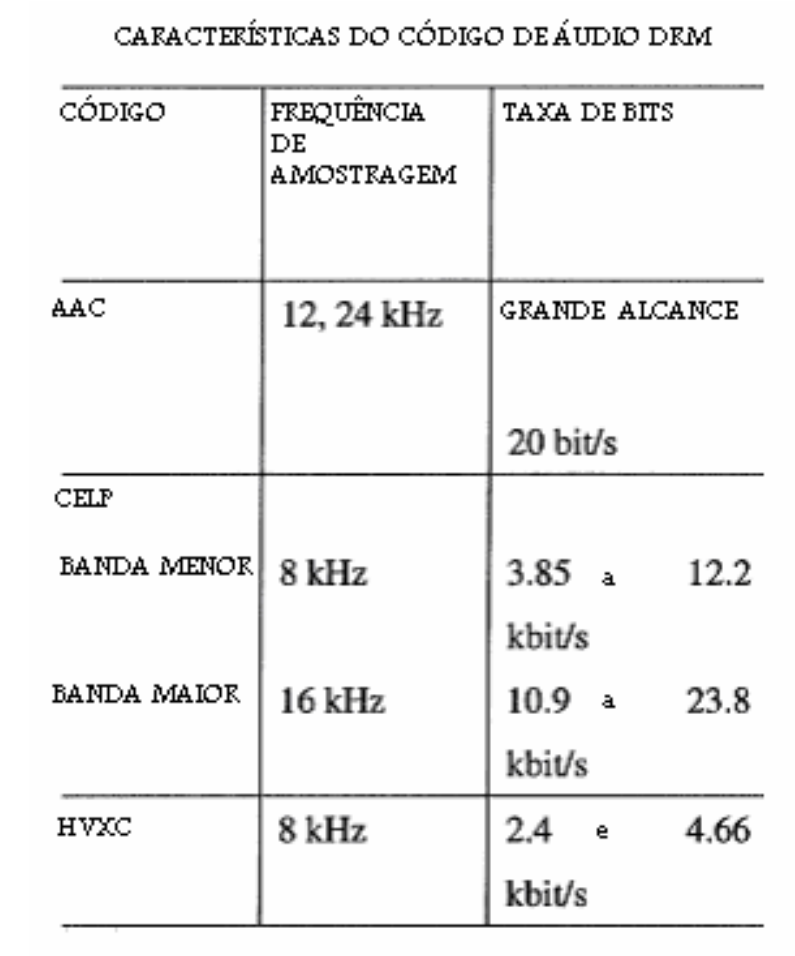

Tabela 3.3: Características dos códigos de áudio DRM.

Portanto duas grandes vantagens podem ser vistas. Primeiro lugar, aplicações de fala com dois ou três idiomas podem ser transmitidos simultaneamente, o que é de grande interesse na radiodifusão internacional. Em segundo lugar, se a taxa de bits disponível é baixa devido à transmissão simulcast ou péssimas condições de canal, a codificação CELP é a candidata preferida. As duas versões do código CELP utilizadas, chamadas de banda larga e de banda estreita, providenciam estabilidade na taxa de bits e na largura de banda. A banda de áudio é de 100 a $3800 \mathrm{~Hz}$ e 50 a $7000 \mathrm{~Hz}$, respectivamente.

O terceiro algoritmo, o HVXC é para novas aplicações de DRM como serviços de multilinguagem e possibilidades de armazenamento de programas de rádio na memória Flash de maneira barata. 


\section{DREAM}

\subsection{SOBRE O DREAM}

O Dream é um projeto de um programa de computador para receber sinais DRM. Esse projeto começou em junho de 2001. A implementação do programa de computador para receber sinais DRM em um computador convencional usando sua placa de som foi motivada pelo fato de a largura de banda do sinal DRM ser menor que $20 \mathrm{kHz}$ e o número de portadoras na modulação OFDM ser relativamente pequena (Máximo de 460)[10].

A intenção do Dream é implementar um programa de computador que funcione como receptor para operar pelo menos com as funções básicas. Desde a criação desse projeto em uma universidade e a idéia fundamental de uma instituição é para ensinar e estimular a criatividade, o código fonte é gratuito no GNU. Ele é um projeto em desenvolvimento que usa modelo de fonte aberta para melhorar a tecnologia DRM. A principal idéia desse projeto é implementar e testar novas pesquisas em um sistema existente, onde a sincronização e o canal de estimação é o principal interesse. A linguagem de programa usado é o $\mathrm{C}++$. O programa roda no Microsoft Windowns e no Linux. O público alvo do programa Dream são aquelas pessoas que estão interessadas em como decodificar o sinal DRM e querem aprender a partir dos algoritmos usados no programa e pessoas que querem ajudar a melhorar a performance do receptor e o código fonte.

Esse programa decodifica canais de $4,5 \mathrm{kHz}, 5 \mathrm{kHz}, 9 \mathrm{kHz}, 10 \mathrm{kHz}, 18 \mathrm{kHz}$ e $20 \mathrm{kHz}$. Ele decodifica também todos os modos A,B,C e D. Faz completa decodificação do FAC, SDC e MSC. Pode-se optar por até 4 iterações do MSC. Decodificação de áudio em AAC, CELP e HVXC.

Além de demodular o sinais DRM, o Dream também demodula sinais analógicos como o AM,LSB,USB e FM. 


\subsection{COMO RECEBER O SINAL DRM}

Qualquer radio receptor de ondas curtas, médias e longas com freqüência intermediária de $455 \mathrm{kHz}$ pode ser usado para receber sinais DRM usando um adaptador que abaixa essa FI para $12 \mathrm{kHz}$. Essa freqüência de FI corresponde à freqüência central que o sinal DRM deve ter para que possa ser processado pela placa de som. A banda ocupada pelo sinal DRM é geralmente $10 \mathrm{kHz}$, e a freqüência máxima de espectro que o Dream aceita é de $24 \mathrm{kHz}$, que é exatamente a maior frequiência que pode ser amostrada por uma placa de som operando com $48 \mathrm{kHz}$ de taxa de amostragem, também conhecida como freqüência de Nyquist. Como o Dream usa $48 \mathrm{kHz}$ de taxa de amostragem e sendo a banda mais usada em DRM a de $10 \mathrm{kHz}$, a FI dever ser maior que $5 \mathrm{kHz}$ e menor que $19 \mathrm{kHz}$ para o bom funcionamento. 


\subsection{ESTRUTURA DO DREAM}

O diagrama de blocos da figura 4.1 mostra as várias etapas que o programa Dream segue para demodular um sinal DRM.

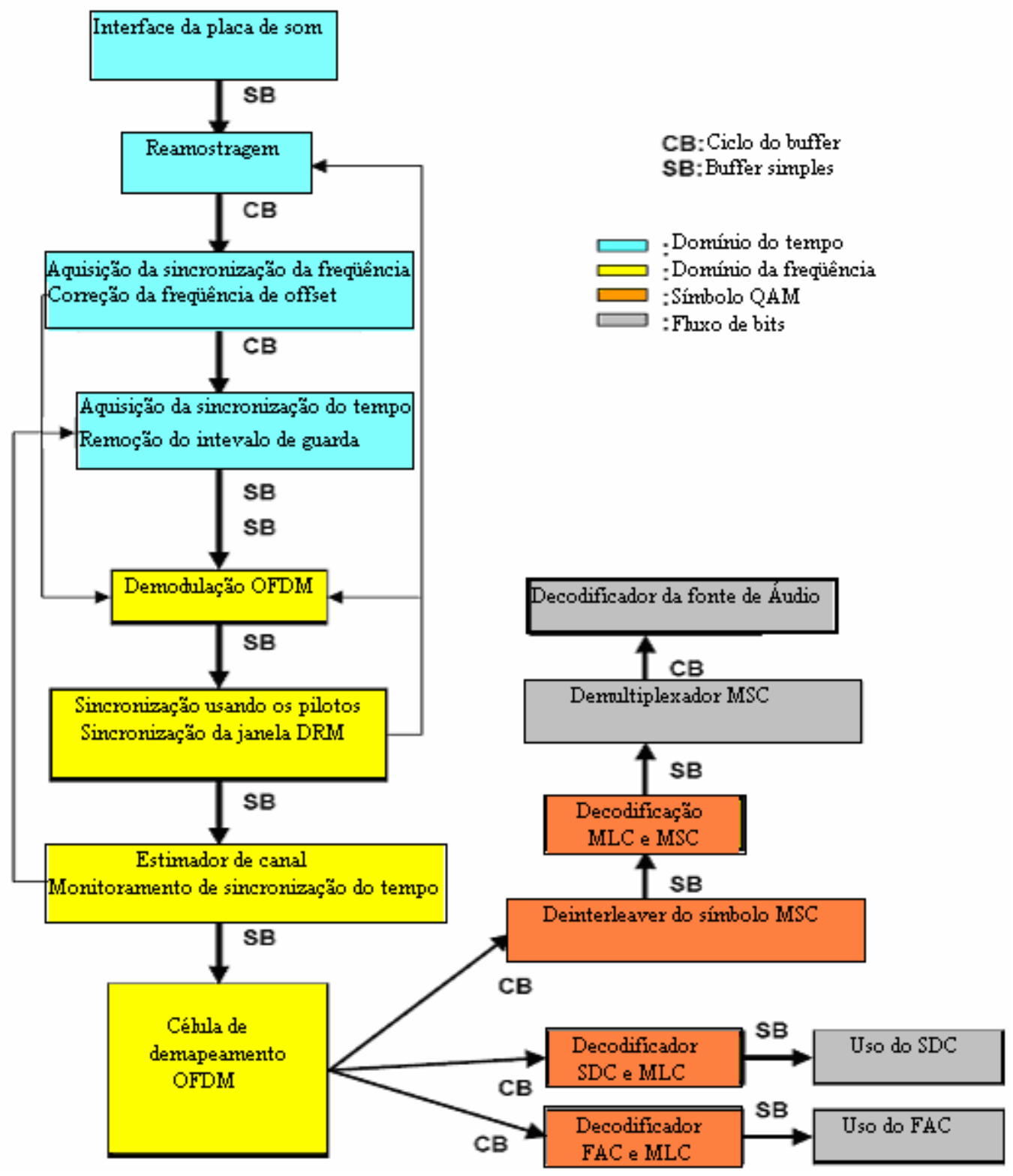

Figura 4.1: Diagrama de Blocos do sistema DREAM.[10] 
A primeira fase é sincronização do tempo e freqüência seguido pelo canal de estimação e equalização. As células FAC são então extraídas da janela recebida e descodificada. O FAC fornece informações sobre a forma de decodificar o SDC e MSC e permite a célula interleaver MSC para ser inicializado para reduzir a latência da descodificação. A próxima etapa consiste em extrair as células SDC e decodificar elas para dar os dados SDC das entidades. Eles fornecem informações sobre como decodificar o MSC (taxas de código, o número e a dimensão das ondas) e informação do decodificador de áudio. Só neste momento o MSC pode ser decodificado, divididos em ondas e enviado para o decodificador de áudio, se necessário.

Subsequente atividades de processamento envolvem atividades de monitoramento do tempo e frequiência de offset, desencadeando novamente se a aquisição do sinal DRM está perdido e respondendo a algumas mudanças na estrutura do sinal DRM, conforme consta na SDC.

Sincronização. Aquisição e sincronização para o sinal DRM são alcançadas pelo processo de correlação no domínio do tempo que busca o período do símbolo de guarda. Isto permite também que tanto o modo OFDM e qualquer subcategoria de não inteiros de frequiência de offset para ser determinada. Frequiências de offset também podem ser calculadas utilizando as três fases piloto contínuas de sons gerados pela freqüência de sincronização de células piloto. Estes sons são projetados para aparecer na mesma frequiência para todos os modos OFDM.

Depois que o início dos símbolos OFDM foi encontrado e a freqüência de offset removida, o sinal pode ser transformado para o domínio da freqüência. O tempo de sincronização de células piloto é então encontrada por um processo de correlação e dar a posição do início de uma janela de transmissão. Estas células piloto também podem ser usadas para dar toda frequiência de offset da subportadora. Sincronização de transmissão de superjanela é obtida apenas após o FAC ter sido descodificado (FAC contém o número da janela). 
Estimação e equalização do canal. O canal de propagação HF, em geral, introduz falha seletiva do tempo e freqüência do sinal recebido. Esta situação tem o efeito de dimensionamento e rotacionamento da constelação do n-QAM e varia em toda a subportadora com o tempo. Essas distorções devem ser corrigidas antes do desmapeamento das células de bit do canal decodificador para que o processo de descodificação funcione adequadamente. Isso é especialmente importante quando se usa constelação de ordem superior, como a 64 QAM. O ganho de referência de células piloto da janela de transmissão são usados em um estimador de canal de interpolação para fornecer estimativas de ganho e a fase da função de transferência do canal em cada subportadora e células de ranhura no tempo. O sinal recebido é, em seguida, equalisado aplicando a função de transferência inversa do canal.

Decodificação de canal. Decodificação de canal é aplicado de forma independente para cada canal lógico e separadamente para cada bloco FAC e SDC bloco e cada janela de multiplexação MSC.

A codificação é projetado de tal forma que os bits correspondentes ao nível 0 ao código de composição são decodificados primeiro. Este mapa de bits para pontos de constelação com uma distância Euclidiana relativamente pequena entre eles e por isso o ruído é susceptível de causar erros de decisão no desmapeamento de células de bit. Por este motivo, os bits de nível 0 são os bits codificados mais robustos. Para codificação com mais de um nível, os bits decodificados de nível 0 são recodificados e usados para selecionar as subconstelações a partir dos bits codificados do nível 1 que estão desmapeados e decodificados. Os pontos nesta subconstelação têm uma distância Euclidiana maior entre eles e por isso são menos propensas à erros de decisão de ruído induzido. Assim, os bits de nível 1 exigem uma menor robustez na codificação.

O processo de usar bits decodificados de níveis mais baixos para bit auxiliar de desmapeamento e decodificação é executada para os bits de nível 2 . Todo o processo pode ser repetido de tal forma que a primeira passagem estimam que os bits de nível 1 e 2 são utilizados para extração auxiliar dos bits do nível e assim por diante, numa forma iterativa.

Variantes no processo de decodificação incluem: a utilização de entradas e saídas suaves para o decodificador convolucional e o número de iterações utilizados no processo de 
decodificação do multiníveis. A seleção do método de decodificação baseia-se num desempenho de solução de compromisso complexo.

Decodificação de áudio. O fluxo de bits de áudio é dividido primeiramente em sua AAC (ou código de discurso) e qualquer componente de dados SBR. O código de discurso AAC é decodificado para formar o menor sinal de banda de freqüência. Se a SBR está em uso, o baixo sinal de banda de freqüência é combinado com os dados da SBR para formar o maior sinal de banda de freqüência. 


\section{ADAPTAÇÕES PARA RECEPÇÃO}

\subsection{INTRODUÇÃO À ANÁLISE DO CIRCUITO}

Nesta seção será discutido o funcionamento do circuito [12]down-converter (Figura 5.1) e, para um melhor entendimento, uma pequena abordagem sobre operações matemáticas envolvendo sinais será apresentada previamente.

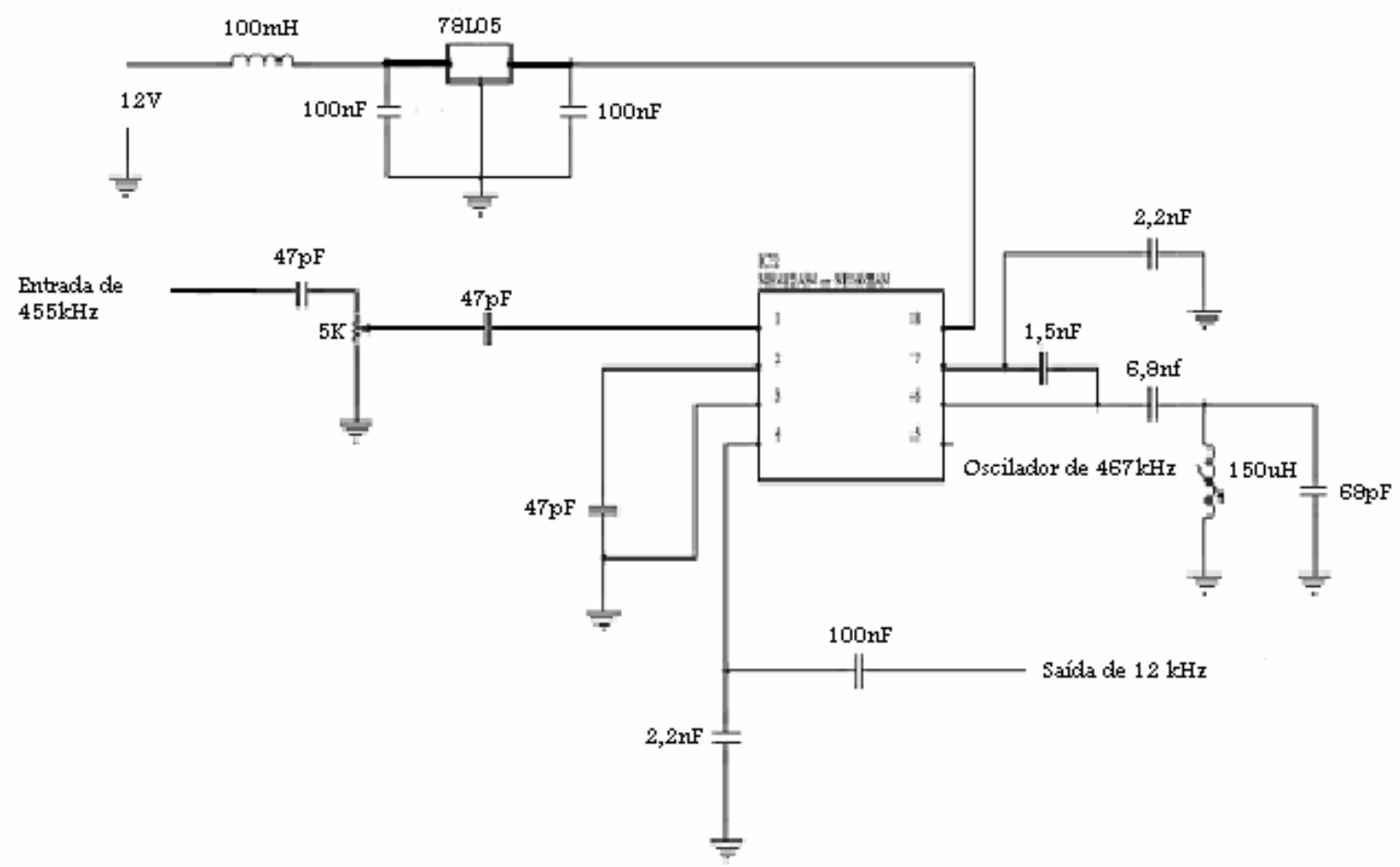

Figura 5.1: Circuito Down-converter

Para que um sinal seja deslocado da banda de transmissão para a banda base e vice e versa, é necessário que este sinal seja multiplicado por outro sinal de alta freqüência, como descrito a seguir.

Seja $g(t)$ um sinal do tipo cosseno de freqüência $\alpha$ e um outro sinal $\mathrm{s}(\mathrm{t})$, também cosseno, de freqüência $\beta$, então, se a multiplicação de um pelo outro for feita, pode-se obter sinais $f(t)$ cuja freqüência é a combinação linear das frequiências dos sinais originais. 


\section{Observe}

$$
\begin{aligned}
& \mathrm{g}(\mathrm{t})=\mathrm{A} \cos \left(\alpha^{*} t\right) \\
& \mathrm{s}(\mathrm{t})=\mathrm{B} \cos \left(\beta^{*} t\right)
\end{aligned}
$$

Se fizer $\mathbf{g}(\mathbf{t}) * \mathbf{s}(\mathbf{t})$, tem-se:

$$
\begin{aligned}
& \mathrm{f}(\mathrm{t})=\mathrm{g}(\mathrm{t}) * \mathrm{~s}(\mathrm{t}) \\
& \mathrm{f}(\mathrm{t})=\mathrm{AB}[\cos (\alpha * t) \cos (\beta * t)]
\end{aligned}
$$

Usando a seguintes identidade trigonométrica:

$$
\begin{aligned}
& \cos (\alpha+\beta)=\cos (\alpha) \cos (\beta)-\sin (\alpha) \sin (\beta) \\
& \cos (\alpha-\beta)=\cos (\alpha) \cos (\beta)+\sin (\alpha) \sin (\beta)
\end{aligned}
$$

somando, encontra-se:

$$
\cos (\alpha) \cos (\beta)=[\cos (\alpha+\beta)+\cos (\alpha-\beta)] / 2
$$

Assim, pode-se reescrever $\mathbf{f}(\mathbf{t})$

$$
\mathrm{f}(\mathrm{t})=(\mathrm{AB} / 2) *[\cos (\alpha+\beta) \mathrm{t}+\cos (\alpha-\beta) \mathrm{t}]
$$

Dessa maneira se os valores de $\alpha$ e $\beta$ são conhecidos e iguais a $467 \mathrm{kHz}$ e $455 \mathrm{kHz}$, respectivamente, então f(t) será:

$$
f(t)=(A B / 2) *[\cos (922 k t)+\cos (12 k t)]
$$

Se o sinal $\mathbf{f}(\mathbf{t})$ passar por um filtro passa baixas, então:

$$
f(t)=(A B / 2) * \cos (12 k t)
$$

Concluída essa etapa de entendimento matemático, pode-se tratar do circuito downconverter, o qual será explicado por partes. Primeiramente será apresentado o CI NE602AN mostrando seu funcionamento e estrutura interna e, em seguida, passa-se a análise dos ramos conectados a cada pino do CI.

\subsection{ANÁLISE DO CI NE602AN}

O circuito do CI NE602AN basicamente fará as operações acima descritas. A estrutura interna do CI e o esquemático dos pinos são vistos na Figura 5.2 abaixo. 
NE602AN
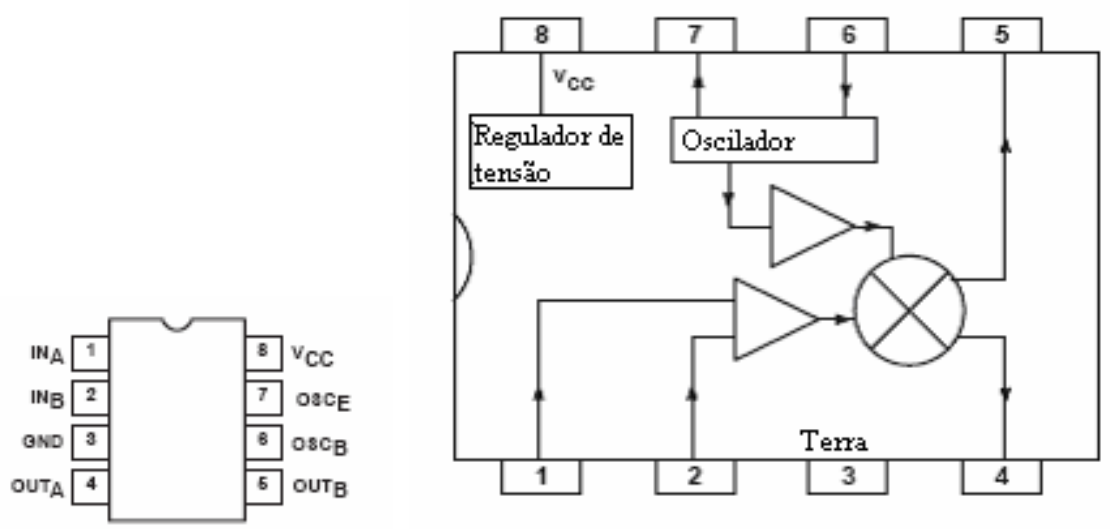

Figura 5.2: CI NE602AN: esquemático e estrutura interna

O NE602AN é um misturador duplamente balanceado com baixa potência, que possui um oscilador e um regulador de voltagem[15]. Foi projetado para atender, a um baixo custo, sistemas de comunicação de baixa potência com sinais de frequiências de $500 \mathrm{MHz}$ e oscilador local de freqüências tão elevadas como 200MHz. O misturador é uma célula de Gilbert [24]em configuração multiplicadora que oferece ganho de $14 \mathrm{~dB}$ ou mais em $45 \mathrm{MHz}$. O oscilador pode ser configurado para um cristal, um tanque sintonizado de operação, ou com um buffer para uma oscilação local externa. O ruído em $45 \mathrm{MHz}$ é tipicamente abaixo de 6dB. O baixo consumo de potencia torna o NE602AN excelente para equipamentos que utilizam bateria, os demais componentes do circuitos beneficiam-se de níveis baixos de radiação energética. O NE602AN é uma célula de Gilbert, um oscilador/buffer. A célula de Gilbert é um amplificador diferencial (Pinos 1 e 2), que dirige uma comutação equilibrada de células. O estágio de entrada diferencial realiza ganho e determina o ruído do sistema. O NE602AN é projetado para otimizar o desempenho de baixa potência. Além de excelente desempenho em baixa potência tem, também, boa performance em VHF. O NE602AN é projetado para ser flexível, assim as entradas, saídas e portas do oscilador podem trabalhar com uma variedade de configurações desde que sejam respeitados certos limites. 
As entradas de RF, pinos 1 e 2, são polarizadas internamente, sendo simétricas. A impedância de entrada AC é de aproximadamente 1,5 k || 3pF operando em 50MHz. Os pinos 1 e 2 podem ser utilizados indiferentemente, mas não devem ser polarizados com uma tensão DC externa. A saída do misturador, pinos 4 e 5, são, também, polarizadas internamente. O oscilador é capaz de sustentar oscilações além $200 \mathrm{MHz}$ com cristal ou com configurações de tanque sintonizado. O limite superior de operação é determinado pelo Q do tanque e conduz aos níveis exigidos[27]. Se a oscilação local requerida está fora dos limites de oscilação ou o sistema solicita uma oscilação local externa, o sinal externo pode ser injetado no pino 6 através de um capacitor que bloqueie o sinal DC. O oscilador externo deve ter tensão mínima de $200 \mathrm{mV}$ pico a pico.

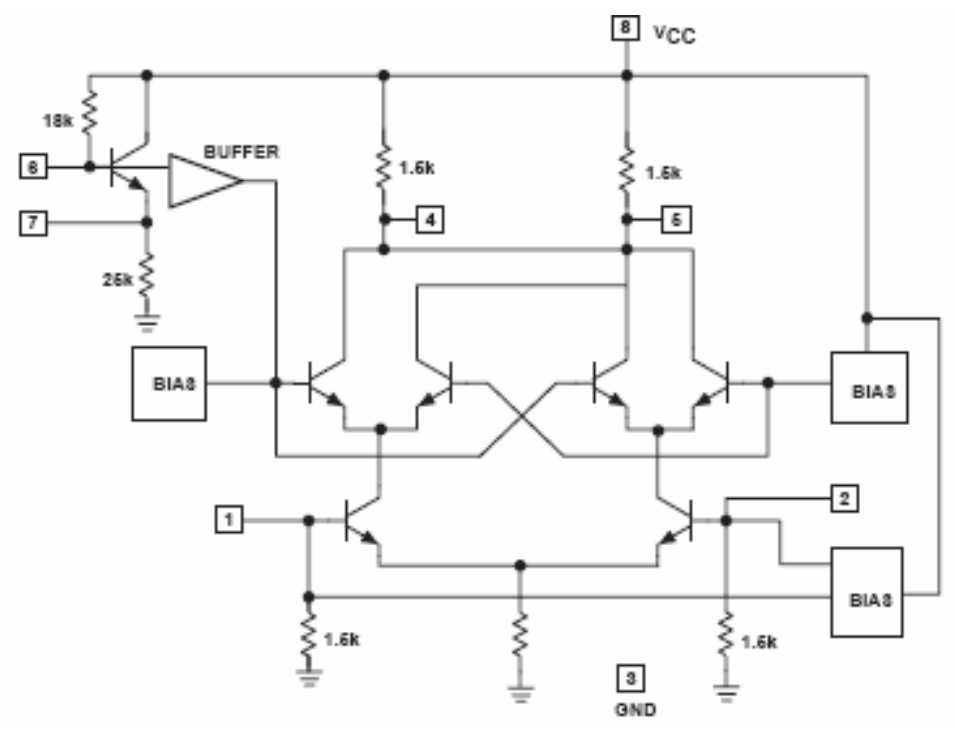

Figura 5.3: Circuito equivalente

A Figura 5.3 mostra o circuito equivalente do dispositivo. O chip é na verdade três subsistemas: A célula misturadora de Gilbert(que fornece ganho na entrada diferencial), um buffer seguidor do oscilador, e um regulador de tensão. A integração completa da polarização DC permite aplicações simples e compactas. A simplicidade do oscilador permite muitas configurações. Tanto cristal como circuito LC tanque podem ser efetivamente empregados. Na Figura 5.4 são vistas as configurações mais comumente utilizadas em suas forma mais básica[21]. 


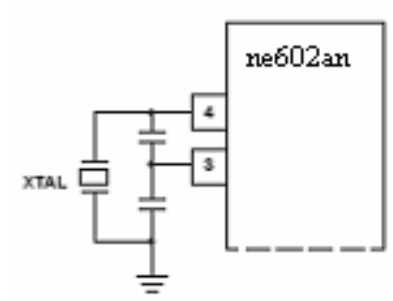

FUNOANENTAL COLPITTA CRYTTAL

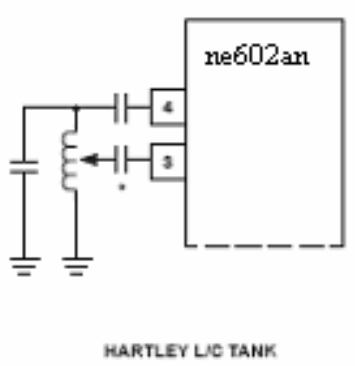

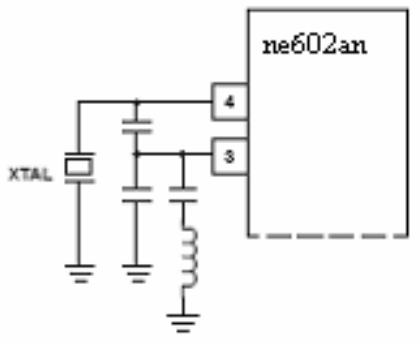

OVERTONE COLPITTS CRYATAL

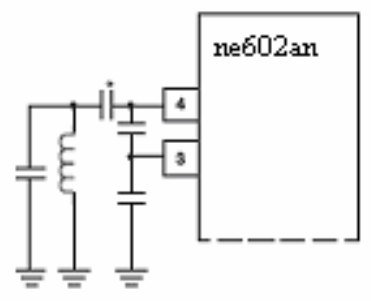

COLPITS LIC TANK

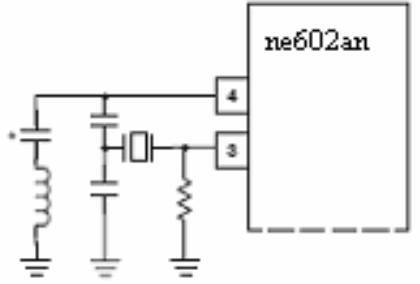

OVERTONE BUTLER CRYTTAL

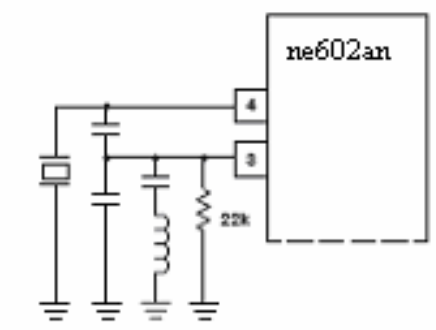

s-sth OVERTONE COLPITT CRVITAL

Figura 5.4: Configurações do circuito oscilador.[20]

Em cada caso o Q do tanque vai afetar os limites superiores da frequiência de oscilação, assim quanto maior o $\mathrm{Q}$ maior a freqüência. $\mathrm{O}$ fator de qualidade $\mathrm{Q}$ é importante para definir o desempenho de um circuito elétrico. Ele é uma medida do grau de seletividade, ou, genericamente, do desempenho do circuito ressonante. Uma definição geral deste parâmetro, aplicável a qualquer sistema ressonante e ao circuito RLC é a seguinte:

$$
Q=\frac{\omega_{0} x(\text { Energia Média Total Armazenada no Circuito })}{\text { Potência Dissipada no Circuito }}
$$

A realimentação depende do $\mathrm{Q}$ do tanque. É recomendável que um montante mínimo de retorno seja utilizado, no entanto a escolha é totalmente empírica.Uma boa solução seria o compromisso entre características iniciais, distorção, frequiência e estabilidade que podem ser rapidamente determinados.

Como pode ser observado o NE602AN realiza a multiplicação, porém para que o sinal de saída tenha a freqüência desejada é preciso polarizar o circuito oscilador do CI de maneira adequada. Existem várias maneiras de polarização, cabendo ao projetista escolher a mais conveniente, ou aquela que atenda de maneira satisfatória às ambições do projeto. 


\subsection{ANÁLISE DOS RAMOS DO CIRCUITO}

Com o entendimento do funcionamento interno do NE 602AN pode-se avançar a análise para entender como serão conectados os componentes de circuito aos pinos do CI, e o porquê das ligações.

Para extração de um sinal de qualidade elevada, na saída do misturador, é importante que o oscilador do circuito esteja fornecendo em uma freqüência constante. Dessa maneira para que o circuito VFO (oscilador de frequiência variável) do NE 602AN opere de maneira estável, faz-se necessária a utilização de um regulador de tensão, que funcionará como uma espécie de isolador para as variações de tensão. A combinação de um 7805 , regulador de tensão, e o NE602AN torna muito estável VFO com um mínimo de esforço[22]. Com isso uma configuração de regulador de tensão é aplicada ao pino 8 como mostrado na Figura 5.5 .

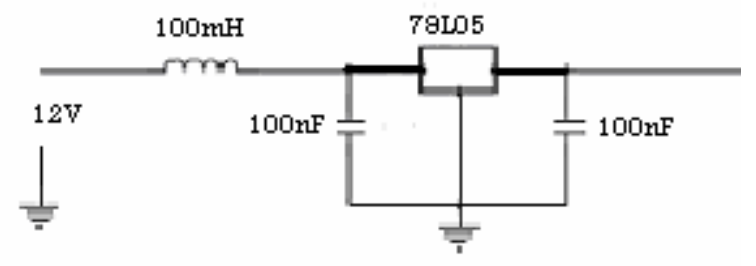

Figura 5.5: Configuração aplicada ao pino 8

Nessa configuração uma tensão DC de $12 \mathrm{~V}$ será aplicada à entrada do indutor e na saída do 7805 estará presente uma tensão de $5 \mathrm{~V}$, o qual é um bom valor de tensão para que o circuito opere. $\mathrm{O}$ indutor junto com o primeiro capacitor estão em uma configuração de filtro passa baixa, de maneira que passe somente o sinal DC. Após o regulador um outro capacitor é conectado ao terra para que uma possível oscilação seja filtrada.

Agora que o CI já esta alimentado e com boas condições de funcionamento, será conectada a entrada do sinal no pino1. 


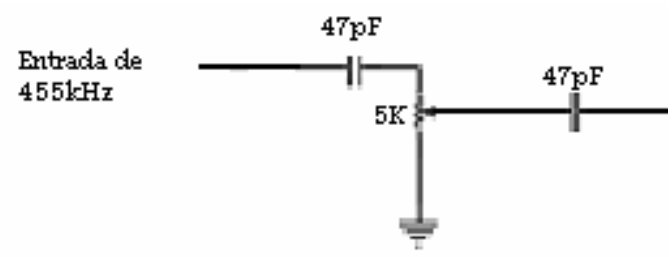

Figura 5.6: Configuração aplicada ao pino 1

Nesse ramo, Figura 5.6, nota-se que o sinal $455 \mathrm{kHz}$ retirado de um receptor de ondas curtas, como será mostrado em seções posteriores, passa por um capacitor de $47 \mathrm{nF}$, um potenciômetro de $5 \mathrm{k}$ e por outro capacitor de $47 \mathrm{nF}$. Os capacitores são responsáveis por eliminar tensões DC e, junto com o potenciômetro, fazem um acoplamento adequado de impedâncias, de modo que o sinal entre de maneira satisfatória no NE602AN.

O pino 2 é simétrico ao pino1, porém não será utilizado como entrada. Como os pino1 e 2 são a entrada de um amplificador diferencial, a célula de Gilbert, e apenas o pino1 está sendo utilizado como entrada, faz-se um aterramento capacitivo no pino 2 de modo que ele não influencie com tensões DC e de nenhuma maneira no ganho da entrada do pino1.

O pino3 é a referencia de terra do NE602AN. Os pinos 4 e 5, são as saídas do misturador, porém apenas o pino 4 será utilizado.

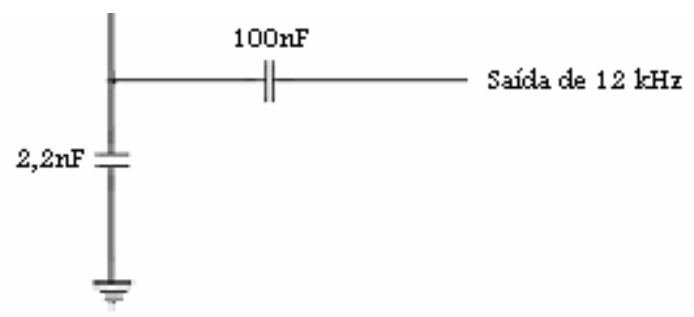

Figura 5.7: Configuração aplicada ao pino 4

Como na saída do misturador estará presente um sinal com componentes de alta e baixa frequiência, para que seja conseguido o final de $12 \mathrm{kHz}$, é necessário que um filtro passa baixa seja projetado. Tal como explicado acima, na descrição matemática do processamento do sinal, o sinal é filtrado pelo capacitor de $2,2 \mathrm{nF}$ e, assim, a saída de $12 \mathrm{kHz}$ desejada está pronta para ser entregue através de um capacitor de acoplamento, Figura 5.7.

Nos pinos 6 e 7 é conectado o circuito responsável pela oscilação local do NE602AN. 


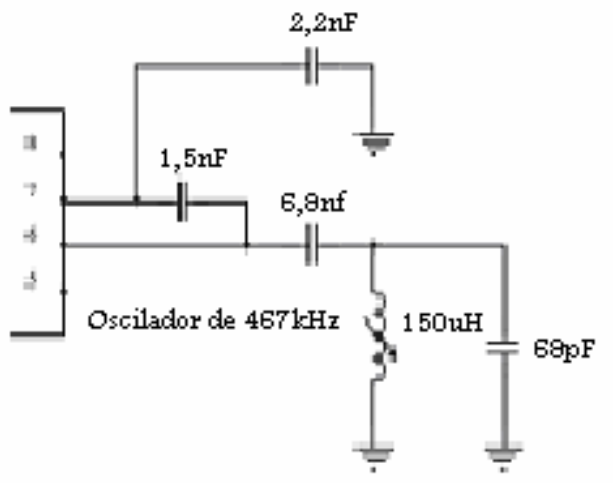

Figura 5.8: Configuração aplicada aos pinos 6 e 7

Como visto anteriormente, na descrição do CI NE602AN, são várias as configurações para polarização do circuito oscilador. No down-converter implementado foi utilizada a configuração colpitts L/C tank, Figura 5.8, cuja facilidade de aquisição dos componentes e estabilidade do circuito foram os fatores determinantes da escolha. Apesar da simplicidade e boa estabilidade dessa configuração, outras implementações foram utilizadas, como mostrado adiante, até que a escolha por essa configuração fosse confirmada.

\subsection{OPÇÕES DE CIRCUITO.}

Para o desenvolvimento do abaixador de frequiência, alguns circuitos foram implementados, todos sugestões de usuários que conseguiram receber DRM e utilizam o DREAM. As características dos circuitos sugeridos, os mais simples e fáceis de serem montados, são muito semelhantes as do circuito descrito anteriormente, com a diferença principal sendo o circuito de excitação do oscilador. Dessa maneira todos os ramos com exceção dos pinos 6 e 7 estão na mesma configuração anterior. 
A primeira opção foi a da Figura 5.9

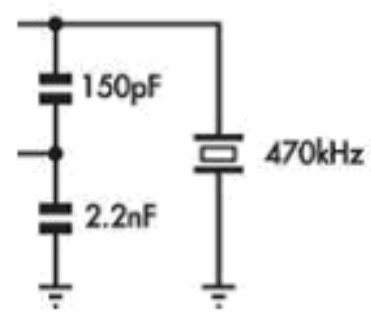

Figura 5.9: Circuito oscilador com ressonador

Nessa opção, com o circuito todo estruturado o único componente que não foi conseguido foi o ressonador cerâmico de $470 \mathrm{kHz}$. Como solução foi utilizado um ressonador com valor mais próximo encontrado no mercado, $500 \mathrm{kHz}$, e com a utilização de duas décadas capacitivas no lugar dos capacitores, com a intenção de abaixar a frequiência do oscilador, foram obtidas freqüências na saída do circuito na faixa de $35 \mathrm{kHz}$ com muita instabilidade.

No segundo circuito implementado, foi utilizado um oscilador externo que através de um acoplamento capacitivo injetou o sinal no pino 7 do NE602AN.

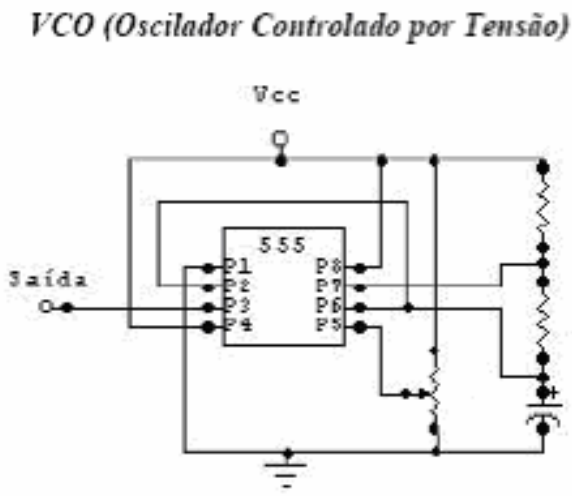

Figura 5.10: Circuito oscilador externo

Assim utilizando o circuito acima, que é uma aplicação do CI NE555 no modo astável(oscilador), foi gerado um oscilador com freqüência variável, pois no lugar dos resistores foram inseridos potenciômetros. Na saída do oscilador, que foi ajustado para uma 
freqüência de $467 \mathrm{kHz}$, era entregue uma onda quadrada que ao passar por um filtro passa baixa com freqüência de corte adequada, gerava um sinal aproximadamente senoidal de frequiência $467 \mathrm{kHz}$, porém com alta instabilidade. Dessa forma na saída do circuito os $12 \mathrm{kHz}$ desejados eram obtidos, porém com muita variação.

\subsection{MODIFICAÇÃO NO SINTONIZADOR AM/FM}

Para concluir com eficiência o processo de recepção DRM através do DREAM só é necessário que um sinal com esse padrão seja sintonizado. Prezando por uma melhor qualidade de recepção, optou-se por utilizar um sintonizador comercial ao invés de uma tentativa de implementação própria que, devido ao tamanho e complexidade do circuito, teria grande possibilidade de ser frustrada.

Com um receptor Gradiente AM/FM modelo S-126, o sinal de freqüência intermediaria do circuito AM, $455 \mathrm{kHz}$, foi retirado e conectado à entrada do circuito abaixador de freqüência (down-converter). Abaixo está descrito o ponto exato de onde o sinal foi retirado.

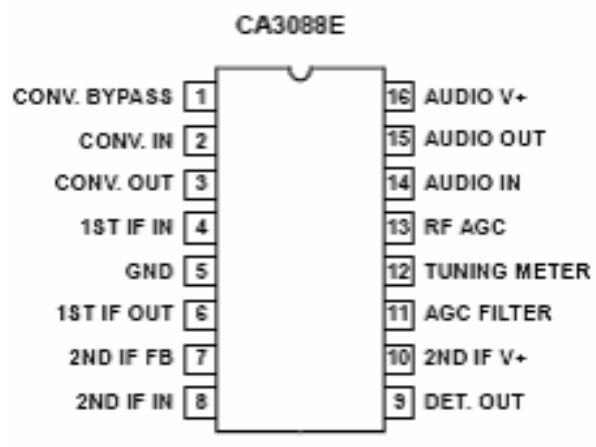

Figura 5.11: CI CA3088E.

O CA3088E é um circuito integrado monolítico, um subsistema AM que providencia a conversão, a amplificação da frequiência intermediária, a detecção e a pré-amplificação do áudio de um receptor AM. No circuito de demodulação AM do receptor gradiente, o CI CA3088E pode ser facilmente identificado e, através de uma conexão feita no pino 8, que é a segunda entrada da freqüência intermediaria deste CI, obtem-se a freqüência de $455 \mathrm{kHz}$ 
desejada. Dessa forma, como mostrado nas figuras abaixo, que são as imagens do osciloscópio no momento dos testes, pode ser notado um sinal que lembra um sinal AM modulado, Figura 5.12, onde a confirmação da frequiência intermediaria desejada pode ser verificada através de sua análise espectral nas Figuras 5.13 e 5.14 .

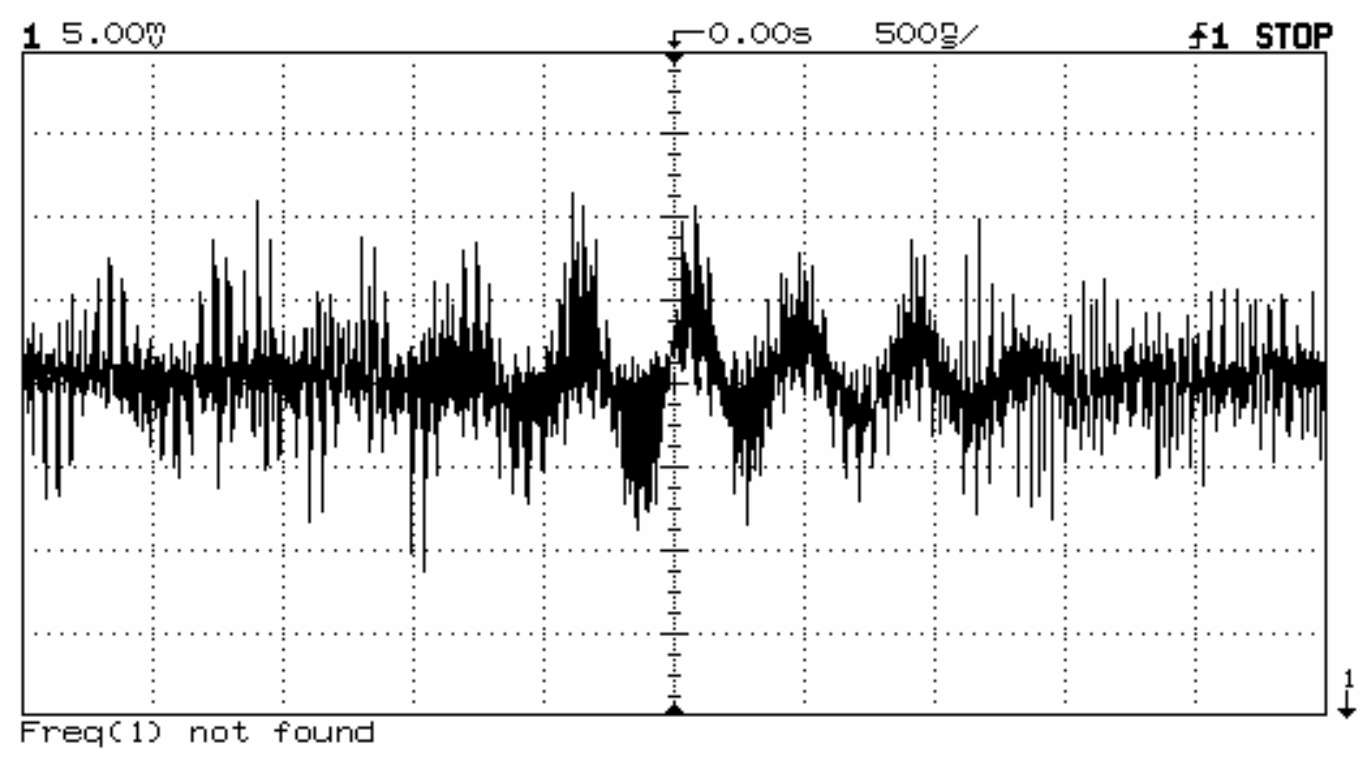

Figura 5.12: Sinal AM em freqüência intermediária de $455 \mathrm{kHz}$

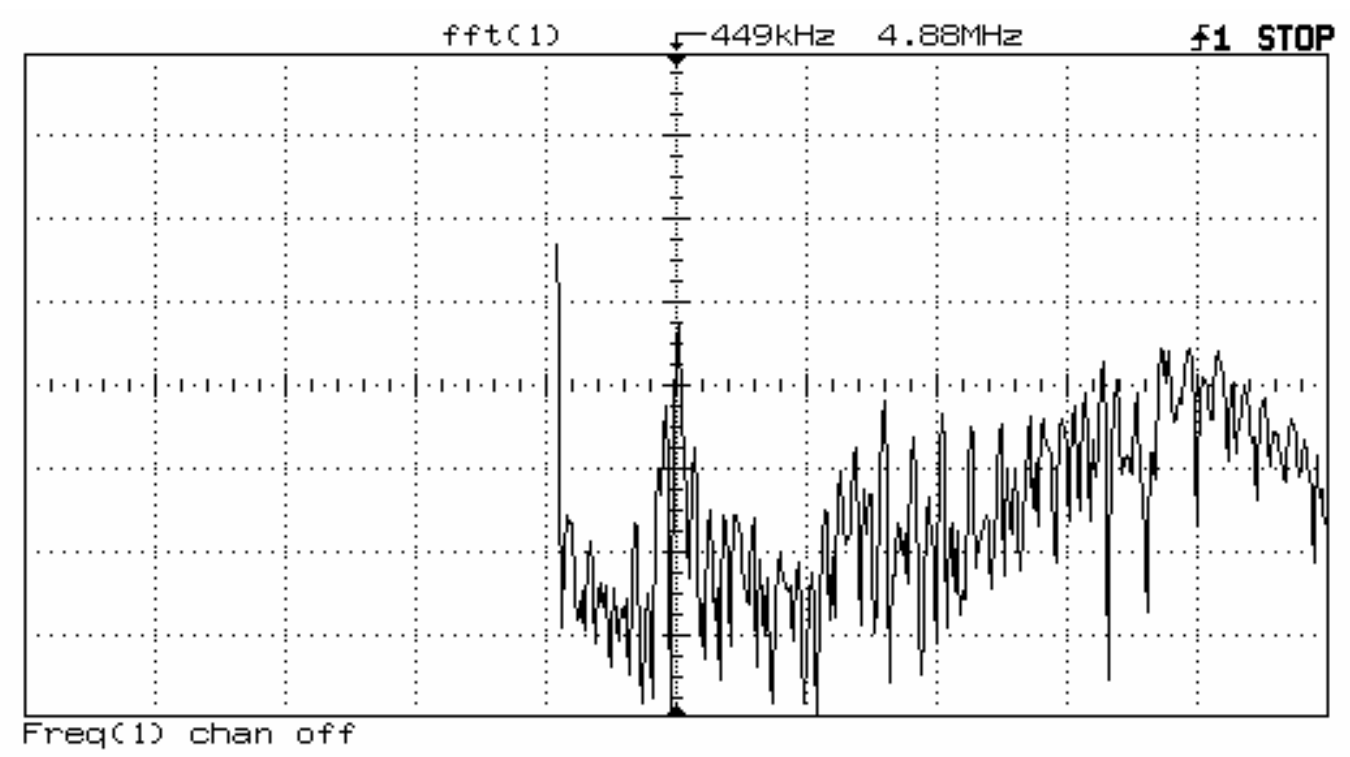

Figura 5.13: Espectro 1 do sinal AM em freqüência intermediária de $455 \mathrm{kHz}$ 


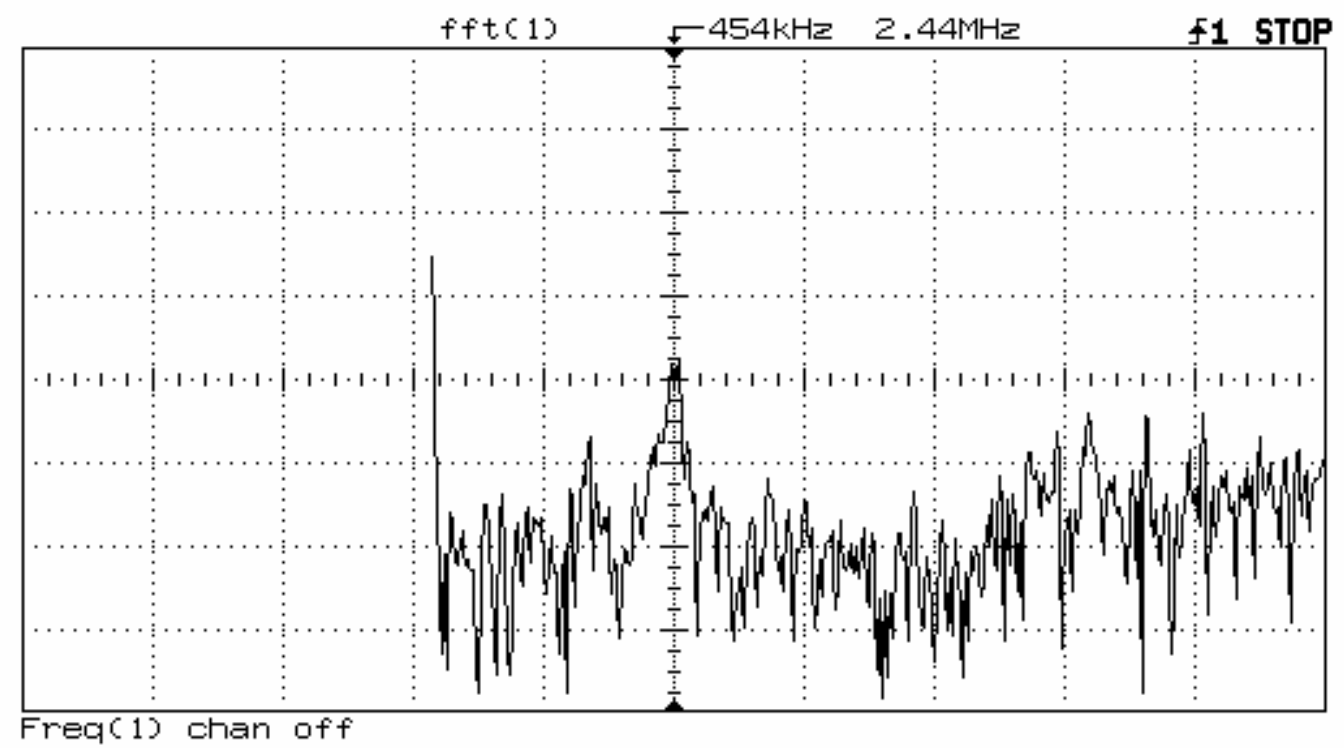

Figura 5.14: Espectro 2 do sinal AM em freqüência intermediária de $455 \mathrm{kHz}$

Pode-se observar dessas figuras um pico na frequiência de $455 \mathrm{kHz}$ que é a portadora do sinal AM na freqüência intermediaria e o espectro do sinal está espalhado ao seu redor.

Conectando o sinal do pino 8 do CI 3088 na entrada do abaixador de freqüência implementado, pode-se observar na saída a mesma onda da Figura 5.12 porém na frequiência de $7 \mathrm{kHz}$. O sinal e seu respectivo espectro foram capturados pelo osciloscópio e são mostrados nas figuras abaixo.

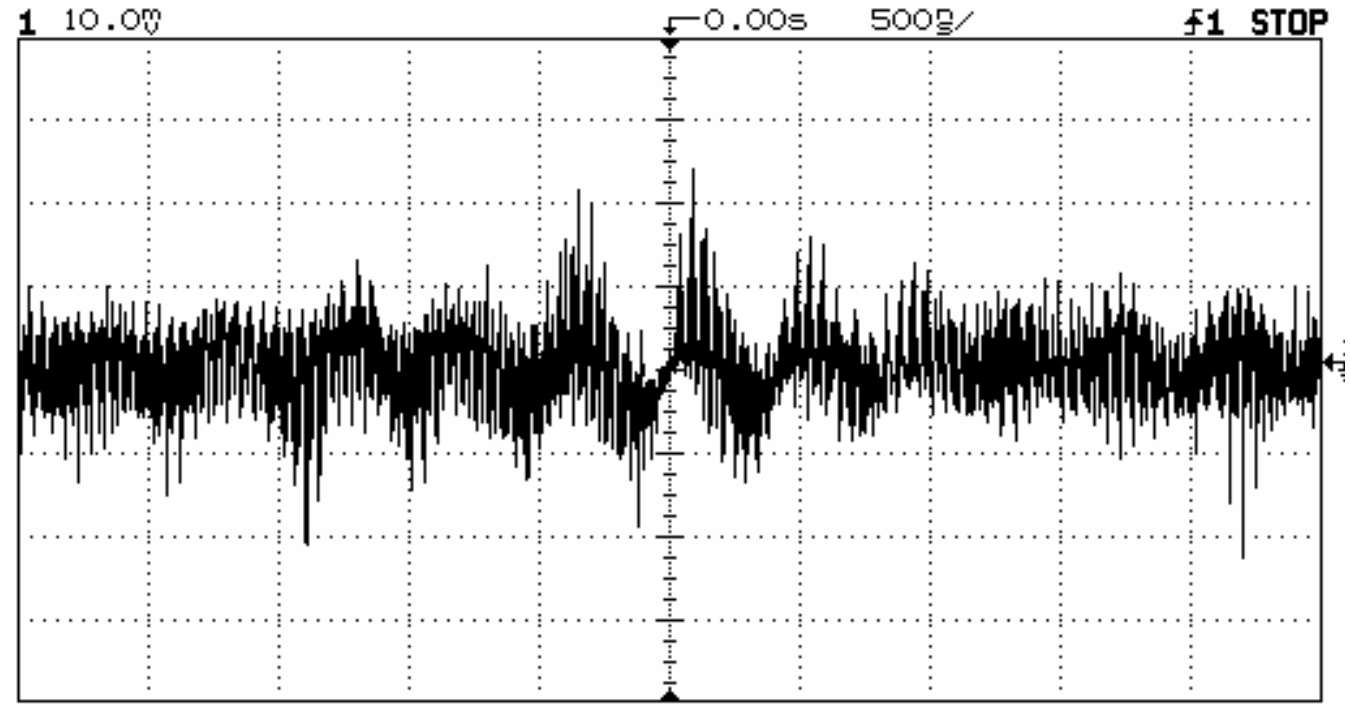

Figura 5.15: Sinal AM na saída do down-converter 


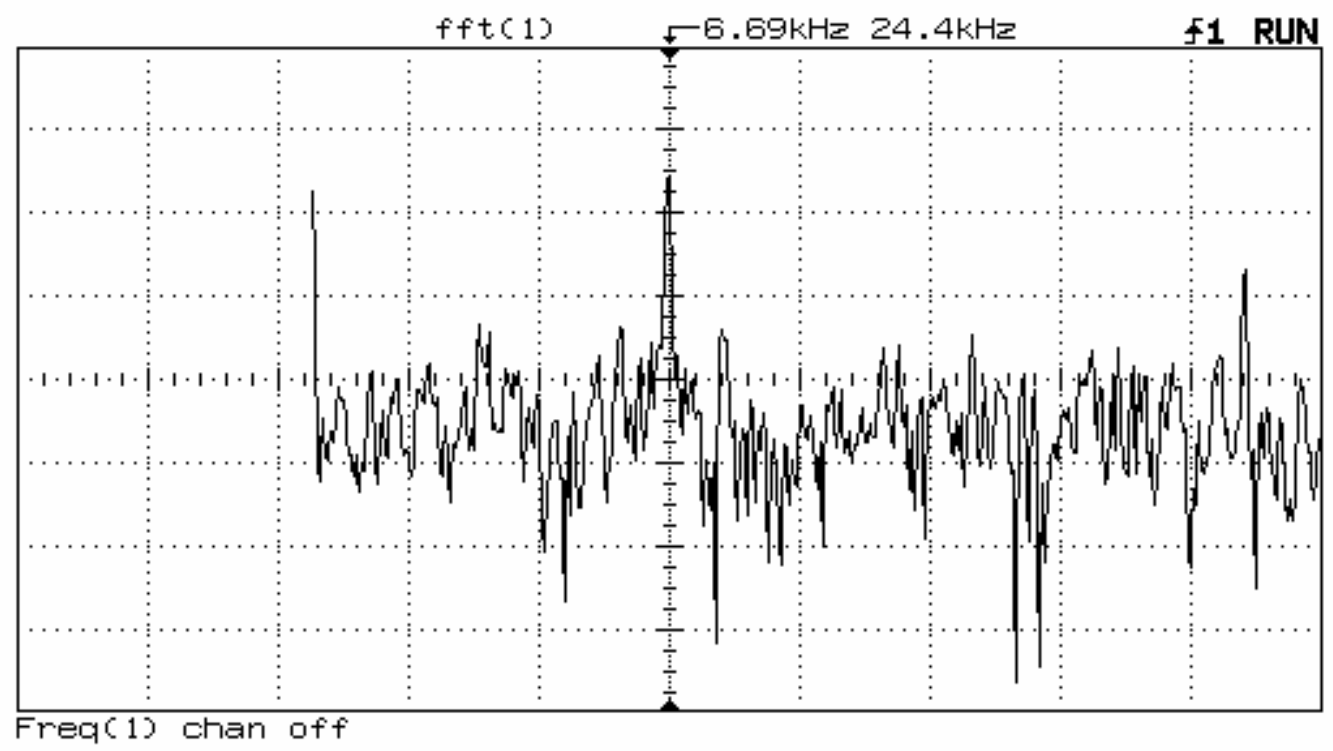

Figura 5.16: Espectro 1 do sinal AM na saída do down-converter

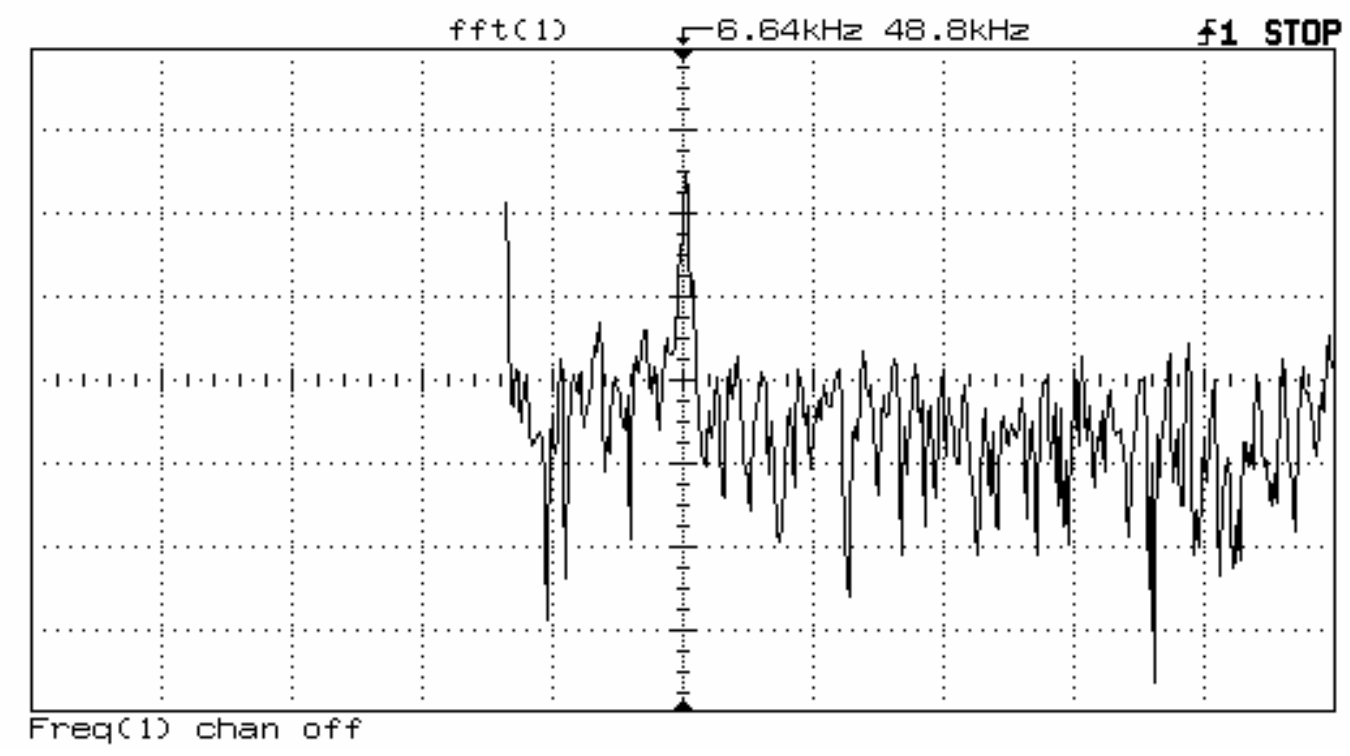

Figura 5.17: Espectro 2 do sinal AM na saída do down-converter

Com esse sinal em uma freqüência baixa, suficiente para ser digitalizada pela placa de som do computador, o software Dream pode receber o sinal sintonizado, como já explicado em seções anteriores, e o espectro do sinal AM pode ser identificado de maneira clara. 


\subsection{TESTES}

Depois de conectar o sinal no computador e abrir o programa Dream, a demodulação é feita automaticamente pelo programa, e o áudio é disponível na saída do auto falante. Foram tiradas algumas imagens com o programa rodando com o sinal AM, assim, pode-se ver que o espectro do sinal é mostrado, e algumas opções como largura de banda e redução de ruído podem ser modificadas para uma melhora do sinal. Essas imagens são mostradas nas figuras abaixo.

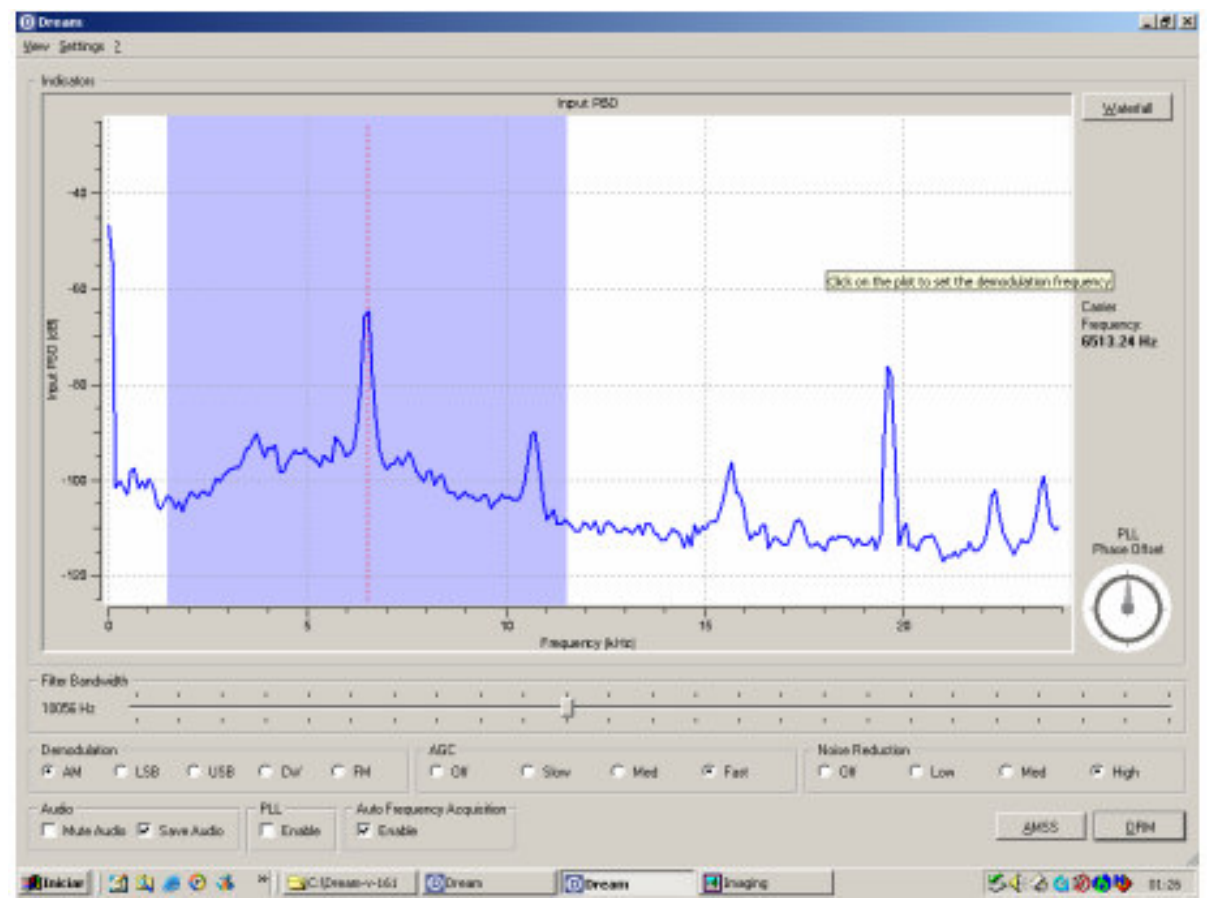

Figura 5.18: Espectro 1 do sinal AM rodado no DREAM 


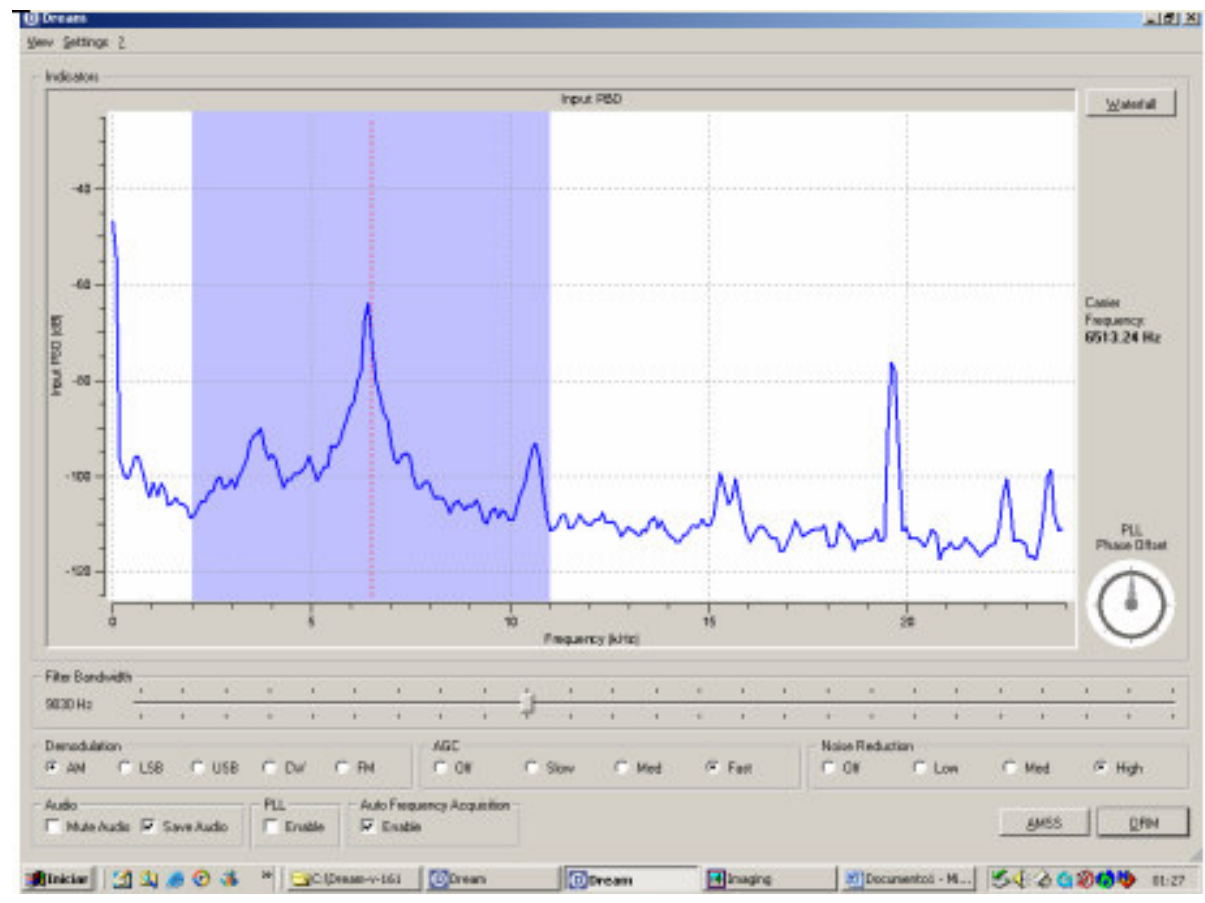

Figura 5.19: Espectro 2 do sinal AM rodado no DREAM

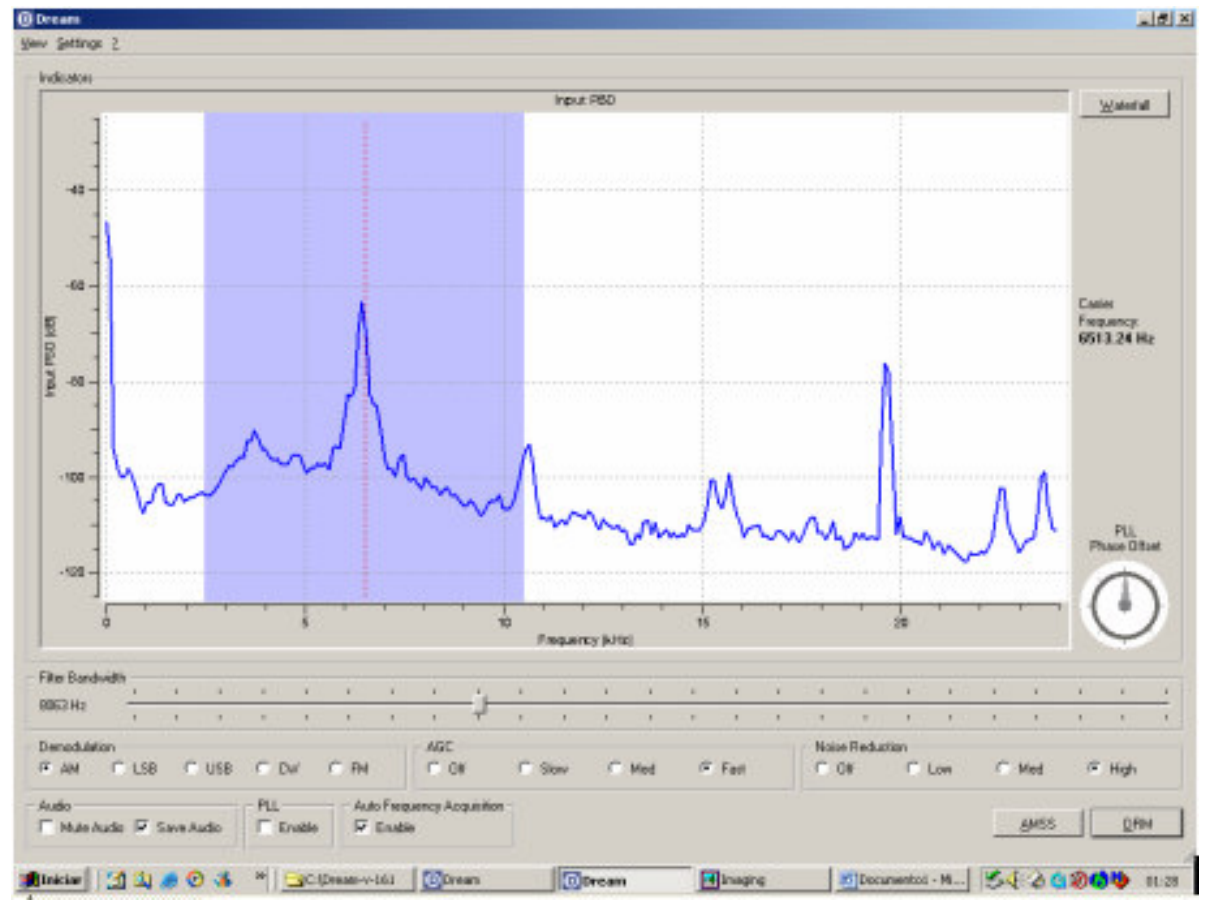

Figura 5.20: Espectro 3 do sinal AM rodado no DREAM

O Dream permite também a gravação do áudio em formato wave. Assim foram feitas algumas gravações para avaliação da qualidade do sinal AM recebido. 
Os testes com o sinal DRM não foram possíveis, pois no princípio, esse projeto foi implementado com intenção de receber um sinal na freqüência de $17860 \mathrm{kHz}$ da estação CVC de Santiago, Chile, todavia não se conseguiu um sintonizador na faixa de ondas curtas. Como alternativa, surgiu a oportunidade de receber os sinais de teste da radiobrás, mas infelizmente as transmissões foram interrompidas antes dos testes se iniciarem. 


\section{CONCLUSÕES}

Diversos padrões de circuitos foram vistos e implementados, sendo que a grande diferença entre eles era a maneira de implementação do circuito oscilador externo conectado aos pinos 6 e 7 do CI NE602AN. As dificuldades de implementação ocorreram na medida que um ou outro elemento do circuito não era obtido no mercado. As soluções para as falhas dos circuitos motivou a procura de outras alternativas de implementação o que levou a uma variedade de possibilidades, onde a melhor estabilidade, facilidade de obtenção de componentes e custo do circuito levou a escolha mostrada na seção 5.1.

Não foi possível a realização dos testes com o sinal digital DRM, pois na falta de um radio de ondas curtas para a recepção do sinal chileno na freqüência de $17860 \mathrm{kHz}$ a única alternativa seria receber o sinal de testes da Radiobrás. Devido ao cronograma do projeto, a realização dos testes se iniciou momentos depois que a Radiobrás encerrou sua transmissão.

Apesar de não terem sido realizado os testes com sinal digital DRM, os testes com sinal analógico AM mostraram que a solução apresentada pode ser válida. O programa Dream operou no modo de demodulação AM com resultado satisfatório. Dessa forma a utilização do abaixador de frequiência acoplado a um receptor comum é boa entrada para o processamento digital utilizando um computador.

Uma sugestão para futuros trabalhos seria a implementação de um sintonizador de ondas curtas, médias e longas, acoplado ao circuito abaixador de freqüência, o que possibilitaria a realização de teste mais variados. O sistema SDR (Rádio Definido por Software) pode ser uma outra alternativa para recepção DRM, necessitando assim que o estudo desse sistema seja realizado para que uma comparação entre os dois sistemas possa indicar a melhor técnica. 


\section{REFERÊNCIAS BIBLIOGRAFICAS}

[1]PSK, disponível em 15/10/07: http://en.wikipedia.org/wiki/Phase-shift_keying

[2]QAM, disponível em 15/10/07:

http://en.wikipedia.org/wiki/Quadrature_amplitude_modulation

[3]A técnica de transmissão OFDM, disponível em 22/08/07:www.cetuc.puc-

rio.br/ amanda.cunha/projeto/OFDM/A\%20t\%82cnica\%20de\%20transmiss\%C60\%200FDM.ppt

[4]Técnica de transmissão OFDM 20/08/07, disponível em:

http://www.maxwell.lambda.ele.puc-rio.br/cgi-

bin/PRG_0599.EXE/10166_3.PDF?NrOcoSis=32731\&CdLinPrg=pt

[5]Página oficial do DRM, disponível em 25/07/07: www.drm.org

[6]Sistemas de radiodifusão de Áudio digital, disponível em 15/10/07:

http://www.lcs.poli.usp.br/ gstolfi/PPT/dab2003.pps

[7]Página da wikipedia sobre DRM, disponível em 14/10/07:

http://en.wikipedia.org/wiki/Digital_Radio_Mondiale

[8]Rádio definido por software,disponível em 11/09/07:

http://ewp.homelinux.net/SDRZero/

[9]DRM, disponível em 11/09/07:

http://agurk.dk/bjarke/Projects/DRM/DRM.htm

[10]Página oficial do Dream, disponível em 05/10/07: http://drm.sourceforge.net/ 
[11]Dream, disponível em 17/09/07:

http://www.skywaves.info/index.php?entityType=HTML\&id=140

[12]Circuito down-converter,disponível em 22/08/07:

http://www.siliconchip.com.au/cms/A_108215/article.html

[13]Modificações de rádios, disponível em 25/10/07:

http://www.monitor.co.uk/radio-mods/dx-394/dx-394-drm-module-installation.htm

[14]DRM - Miniature Mixer Unit with crystal option, disponível em12/09/07:

http://www.sat-schneider.de/download/Mixerflyer.pdf

[15]Notas de aplicação AN1983, disponível em 12/09/07:

http://www.nxp.com/acrobat_download/applicationnotes/AN1983.pdf

[16]NE602 or NE612 DOUBLE BALANCED MIXER , disponível em 12/09/07:

http://www.electronics-tutorials.com/devices/602.htm

[17]Referências NE602,disponível em 12/09/07:

tex.net/usr/r/receivers/ra01087.htm

[18]Notas de aplicação AN1982, disponível em 15/09/07:

http://www.nxp.com/acrobat_download/applicationnotes/AN1982.pdf

[19]Notas de aplicação AN1993, disponível em 15/09/07:

http://www.standardics.nxp.com/support/documents/rf/pdf/an1993.pdf

[20]Notas de aplicação AN1994, disponível em15/09/07:

http://www.standardics.nxp.com/support/documents/rf/pdf/an1994.pdf 
[21]Referências NE602, disponível em 12/09/07:

http://docs-europe.electrocomponents.com/webdocs/0027/0900766b80027aa2.pdf

[22]Regulador de tensão,disponível em 23/10/07: http://www.pan-

tex.net/usr/r/receivers/ra01106.htm

[23]Osciladores, disponível em 25/10/07:

http://info.awmn.net/users/images/stories/Library/RadioTheory/ARRL\%20HANDBOOK

$\% 202001 / 14 . p d f$

[24]Célula de Gilbert, disponível em13/09/07:

http://michaelgellis.tripod.com/gilbert.html

[25]Célula de Gilbert, disponível em 13/09/07:

http://www.odyseus.nildram.co.uk/RFIC_Circuits_Files/MOS_Gilbert_Cell_Mixer.pdf

[26]Oscilador,disponível em 25/10/07:

http://www.allaboutcircuits.com/vol_2/chpt_6/5.html

[27]Oscilador em realimentação,disponível em 25/10/07:

http://www.maxwell.lambda.ele.puc-rio.br/cgi-

bin/PRG_0599.EXE/7590_4.PDF?NrOcoSis=21813\&CdLinPrg=pt

[28] Disponível no artigo: MODULATION Systems (Part 2) 
